\title{
Spring phytoplankton communities of the Labrador Sea (2005-2014): pigment signatures, photophysiology and elemental ratios
}

\author{
Glaucia M. Fragoso ${ }^{1}$, Alex J. Poulton ${ }^{2}$, Igor M. Yashayaev ${ }^{3}$, Erica J. H. Head ${ }^{3}$, and Duncan A. Purdie ${ }^{1}$ \\ ${ }^{1}$ Ocean and Earth Science, University of Southampton, National Oceanography Centre Southampton, Southampton, UK \\ ${ }^{2}$ Ocean Biogeochemistry and Ecosystems, National Oceanography Centre, Southampton, UK \\ ${ }^{3}$ Ocean and Ecosystem Science Division, Department of Fisheries and Oceans, Bedford Institute of Oceanography, \\ Dartmouth, NS, Canada
}

Correspondence to: Glaucia M. Fragoso (glaucia.fragoso@noc.soton.ac.uk)

Received: 15 July 2016 - Discussion started: 22 July 2016

Revised: 20 January 2017 - Accepted: 5 February 2017 - Published: 14 March 2017

\begin{abstract}
The Labrador Sea is an ideal region to study the biogeographical, physiological, and biogeochemical implications of phytoplankton community composition due to sharp transitions between distinct water masses across its shelves and central basin. We have investigated the multiyear (2005-2014) distributions of late spring and early summer (May to June) phytoplankton communities in the various hydrographic settings of the Labrador Sea. Our analysis is based on pigment markers (using CHEMTAX analysis), and photophysiological and biogeochemical characteristics associated with each phytoplankton community. Diatoms were the most abundant group, blooming first in shallow mixed layers of haline-stratified Arctic shelf waters. Along with diatoms, chlorophytes co-dominated at the western end of the section (particularly in the polar waters of the Labrador Current (LC)), whilst Phaeocystis co-dominated in the east (modified polar waters of the West Greenland Current (WGC)). Pre-bloom conditions occurred in deeper mixed layers of the central Labrador Sea in May, where a mixed assemblage of flagellates (dinoflagellates, prasinophytes, prymnesiophytes, particularly coccolithophores, and chrysophytes/pelagophytes) occurred in low-chlorophyll areas, succeeding to blooms of diatoms and dinoflagellates in thermally stratified Atlantic waters in June. Light-saturated photosynthetic rates and saturation irradiance levels were highest at stations where diatoms were the dominant phytoplankton group ( $>70 \%$ of total chlorophyll $a$ ), as opposed to stations where flagellates were more abundant (from 40 up to $70 \%$ of total chlorophyll $a$ ). Phytoplankton communities
\end{abstract}

from the WGC (Phaeocystis and diatoms) had lower lightlimited photosynthetic rates, with little evidence of photoinhibition, indicating greater tolerance to a high light environment. By contrast, communities from the central Labrador Sea (dinoflagellates and diatoms), which bloomed later in the season (June), appeared to be more sensitive to high light levels. Ratios of accessory pigments (AP) to total chlorophyll $a$ (TChl $a$ ) varied according to phytoplankton community composition, with polar phytoplankton (cold-water related) having lower AP: TChl $a$. Polar waters (LC and WGC) also had higher and more variable particulate organic carbon (POC) to particulate organic nitrogen (PON) ratios, suggesting the influence of detritus from freshwater input, derived from riverine, glacial, and/or sea ice meltwater. Long-term observational shifts in phytoplankton communities were not assessed in this study due to the short temporal frame (May to June) of the data. Nevertheless, these results add to our current understanding of phytoplankton group distribution, as well as an evaluation of the biogeochemical role (in terms of $\mathrm{C}: \mathrm{N}$ ratios) of spring phytoplankton communities in the Labrador Sea, which will assist our understanding of potential long-term responses of phytoplankton communities in high-latitude oceans to a changing climate. 


\section{Introduction}

Marine phytoplankton form a taxonomically and functionally diverse group, where communities are structured by a variety of factors, including nutrient and light availability, predation and competition for resources (Litchman and Klausmeier, 2008). Such environmental heterogeneity creates biogeographical patterns of abundance, composition, traits, and diversity of phytoplankton communities in the global ocean (Barton et al., 2013; Follows et al., 2007; Hays et al., 2005). Phytoplankton communities within a biogeographical region are subject to similar environmental conditions, such as temperature (Bouman et al., 2003), nutrient concentration (Browning et al., 2014), and irradiance (Arrigo et al., 2010). These environmental factors, along with phytoplankton community composition itself (Bouman et al., 2005), affect the overall photo-physiological response and bulk rates of primary production.

The biogeography of phytoplankton communities and their photophysiological characteristics, consequently, directly impact the structure of marine ecosystems due to their functional roles in biogeochemical cycling and the transfer of energy to higher trophic levels. For example, distinct phytoplankton assemblages influence particulate (Martiny et al., 2013a, b; Smith and Asper, 2001) and dissolved elemental stoichiometry (C:N:P) (Weber and Deutsch, 2010), the drawdown of gases (Arrigo, 1999; Tortell et al., 2002) and the efficiency of carbon export (Guidi et al., 2009; Le Moigne et al., 2015) in different ways. Patterns of phytoplankton stoichiometry may be consistent phylogenetically within higher taxonomic levels (Ho et al., 2003; Quigg et al., 2003); however, stoichiometry also varies according to nutrient supply ratios (Bertilsson et al., 2003; Rhee, 1978) and phenotypically within species of the same population (Finkel et al., 2006).

The subarctic North Atlantic is a complex system with contrasting hydrography that structures plankton communities within distinct biogeographical provinces (Fragoso et al., 2016; Head et al., 2003; Li and Harrison, 2001; Platt et al., 2005; Sathyendranath et al., 1995, 2009). Biogeographical regions of the Labrador Sea shape phytoplankton community composition (Fragoso et al., 2016), bio-optical properties (Cota, 2003; Lutz et al., 2003; Platt et al., 2005; Sathyendranath et al., 2004; Stuart et al., 2000), and the seasonality of phytoplankton blooms (Frajka-Williams and Rhines, 2010; Lacour et al., 2015; Wu et al., 2007, 2008). Phytoplankton blooms, for example, occur first (April to early May) on the shelves due to haline stratification driven by the input of Arctic-related waters, in addition to rapid sea ice melt on the Labrador Shelf near Canada (Frajka-Williams and Rhines, 2010; Wu et al., 2007). The central Labrador bloom occurs later in the season (late May to June) as a result of thermal stratification (Frajka-Williams and Rhines, 2010). Fragoso et al. (2016) showed that the biogeography of phytoplankton communities in the Labrador Sea during spring and early summer is shaped by distinct species found in Atlantic or Arctic waters, which may have distinct influences on biogeochemical cycles and the transfer of energy to upper trophic levels. However, these authors focused on taxonomy and only investigated relatively large phytoplankton $(>4 \mu \mathrm{m})$. The photophysiological and biogeochemical signatures, such as particulate matter stoichiometry $(\mathrm{C}: \mathrm{N}$ ratio) of these different spring phytoplankton communities occurring in distinct sectors of the Labrador Sea have not been investigated.

Quantification of marine phytoplankton community composition, for a large numbers of samples, is challenging due to small cells $(<4 \mu \mathrm{m})$ being difficult to identify and accurately count using light microscopy, in addition to being a very time-consuming method. To overcome these problems, quantification and analyses of phytoplankton pigments by high-performance liquid chromatography (HPLC) has been widely used to monitor phytoplankton community distributions over large temporal and spatial scales (e.g. Aiken et al., 2009; Peloquin et al., 2013; Platt et al., 2005). The interpretation of the pigment data is not always straightforward, since some pigments are shared by several algal groups and can vary according to local nutrient and light conditions (e.g. DiTullio et al., 2007; van Leeuwe and Stefels, 1998, 2007). The chemotaxonomic tool, CHEMTAX (CHEMical TAXonomy), provides a valuable approach to estimate phytoplankton group abundances when used in conjunction with microscopic information (Irigoien et al., 2004; Mackey et al., 1996; Wright et al., 1996). CHEMTAX has the advantage of providing more information about phytoplankton groups than individual diagnostic pigments or ratios and has been used widely to investigate phytoplankton biogeography on regional scales (e.g. Muylaert et al., 2006; Wright and Van den Enden, 2000) and globally (e.g. Swan et al., 2015).

Here, we investigated the multi-year (2005-2014) distributions of late spring and early summer (May to June) phytoplankton communities in the various hydrographic settings across the shelves, slopes, and deep basin of the Labrador Sea based on phytoplankton pigments. In addition, we also examined the overall photophysiological and biogeochemical traits associated with these different phytoplankton communities. The purpose of this study was to answer the following questions: were there distinct phytoplankton communities in the Labrador Sea and if so, what were their main constituents? How did spatial and temporal variability in environmental factors explain the phytoplankton community distribution and composition? What were the linkages between community composition and variability in both particulate matter stoichiometry (i.e. $\mathrm{C}: \mathrm{N}$ ratios) and photophysiological traits (parameters of the photosynthesis versus irradiance relationships) across the Labrador Sea?

Our results provide a geographical description of the phytoplankton community structure in spring and early summer surface waters of the Labrador Sea based on pigment data and CHEMTAX analysis from over a decade of sampling 
(2005-2014). We show that several distinct phytoplankton communities exist, which vary between the different hydrographic zones of the Labrador Sea, and that they present variable patterns in terms of $\mathrm{C}: \mathrm{N}$ ratios and photophysiological responses to environmental conditions.

\section{Methods}

\subsection{Study area}

The Labrador Sea is a high-latitude marginal sea located in the northwestern part of the Atlantic Ocean, and is an important transition zone between Arctic and subarctic ecosystems (Fig. 1). It is bounded by Davis Strait to the north, a line from Cape St Francis in Newfoundland $\left(47^{\circ} 45^{\prime} \mathrm{N}\right.$, $52^{\circ} 27^{\prime} \mathrm{W}$ ) to Cape Farewell (southern tip of Greenland) to the southeast, and the coast of Labrador and Newfoundland to the west (Fig. 1) (International Hydrography Organization, 1953). The bathymetry of the Labrador Sea can be subdivided into the wide continental shelf and relatively gentle continental slope on its western side (the Labrador Shelf, $>500 \mathrm{~km}$ wide and $<250 \mathrm{~m}$ deep) and the narrow shelf and steep continental slope on the eastern side (the Greenland Shelf and Slope, $<100 \mathrm{~km}$ wide and $<2500 \mathrm{~m}$ deep).

The upper Labrador Sea $(<200 \mathrm{~m})$ is comprised of waters originating from the North Atlantic and the Arctic (Yashayaev, 2007). Atlantic-influenced waters occur mostly in the central Labrador Sea, where waters are relatively warm, salty, and mainly identified as the Irminger Current (IC). Cold, low-salinity waters originate from the Arctic via the surrounding shelves and are mainly identified as the Labrador Current (LC) and the West Greenland Current (WGC) (Fig. 1). Circulation in the central basin of the Labrador Sea is complex, often showing a gyre-like flow system that alternates in direction (Palter et al., 2016; Wang et al., 2016).

The inshore branch of the LC overlies the Labrador Shelf and includes Arctic waters originating from Baffin Bay and the Canadian Arctic Archipelago via Davis Strait and from Hudson Bay via Hudson Strait, together with inputs of melting sea ice that originates locally or from further north. The main branch of the LC flows along the Labrador slope from north to south and is centred around the $1000 \mathrm{~m}$ depth contour. It is composed of a mixture of Arctic water from Baffin Bay via Davis Strait and the branch of the WGC that flows west across the mouth of Davis Strait. The WGC, which flows from south to north over the Greenland Shelf and along the adjacent slope, is a mixture of cold, low-salinity Arctic water exiting the Nordic Seas with the East Greenland Current (EGC) (Yashayaev, 2007), together with sea ice and glacial melt water (Fig. 1). The WGC often spreads westwards, forming a "tongue" of buoyant freshwater, where accumulation of low-salinity waters is driven by high eddy kinetic activity in the central eastern Labrador Sea during

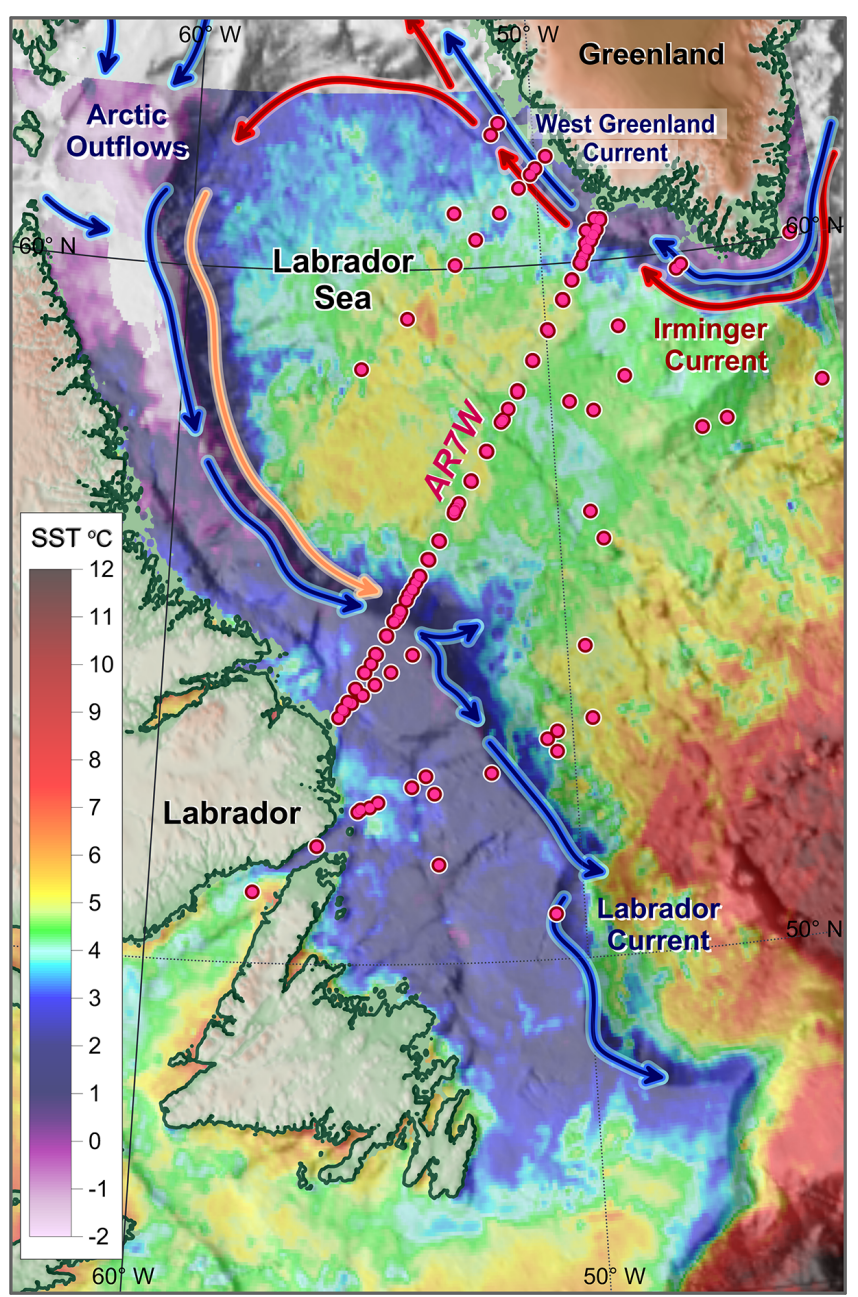

Figure 1. Map showing stations along the AR7W transect and additional stations sampled during late spring and early summer (20052014). The station positions are superimposed on a composite image of sea surface temperature for the last 3 weeks of May 2006 collected by the NOAA satellite (AVHRR). White patches represent ice (Labrador and Greenland coasts). Circulation elements - colder currents (Labrador Current, Arctic outflows, and West Greenland Current, blue solid arrows), warmer currents (Irminger Current (IC) and extension, dark red and light solid arrows, respectively). The extended branch of the IC is a modified (cooled and freshened) water mass caused by lateral and vertical mixing along the Labrador slope.

spring (Frajka-Williams and Rhines, 2010). The WGC often floats over the IC in the central-eastern part of the Labrador Sea; however, the IC is usually observed in surface waters of the central-western Labrador Sea during spring. More detailed descriptions of the hydrography of the Labrador Sea can be found elsewhere (e.g. Fragoso et al., 2016, Head et al., 2013; Yashayaev and Seidov; Yashayaev, 2007). 
Table 1. Research cruises, sampling dates, and number of samples per cruise $(n)$ where pigment data were collected in the Labrador Sea during early spring and late summer (2005-2014). HUD-YearID and JR302 refer to expeditions carried out on board the CCGS Hudson (Canada) and RRS James Clark Ross (UK), respectively.

\begin{tabular}{llrr}
\hline Cruise & Dates & Year & $n$ \\
\hline HUD-2005-016 & 29 May-3 June & 2005 & 25 \\
HUD-2006-019 & 23-31 May & 2006 & 12 \\
HUD-2007-011 & 11-21 May & 2007 & 32 \\
HUD-2008-009 & 22-29 May & 2008 & 25 \\
HUD-2009-015 & 18-23 May & 2009 & 26 \\
HUD-2010-014 & 14-24 May & 2010 & 27 \\
HUD-2011-009 & 11-17 May & 2011 & 33 \\
HUD-2012-001 & 3-11 June & 2012 & 30 \\
HUD-2013-008 & 9-21 May & 2013 & 27 \\
JR302 & 10-24 June & 2014 & 16 \\
\hline
\end{tabular}

\subsection{Sampling}

Data used for this study were obtained along the AR7W Labrador Sea hydrography line (World Ocean Circulation Experiment Atlantic Repeat 7-West section, for details see Fragoso et al., 2016), which runs between Misery Point on the Labrador coast (through Hamilton Bank on the Labrador Shelf) and Cape Desolation on the Greenland coast. Stations were sampled during late spring and/or early summer, varying within a 6-week window (see sampling dates in Table 1) over a period of 10 years (2005-2014) by scientists from the Bedford Institute of Oceanography (BIO), Canadian Department of Fisheries and Oceans. Fixed stations (total of 28), as well as some additional non-standard stations, were sampled across the shelves and central basin on the AR7W section, or slightly north or south of this transect (Fig. 1).

Vertical profiles of temperature and salinity were measured with a Sea-Bird CTD system (SBE 911). Seawater samples were collected using $10 \mathrm{~L}$ Niskin bottles mounted on a rosette frame. Mixed-layer depths were calculated from the vertical density $\left(\sigma_{O}\right)$ distribution and defined as the depth where $\sigma_{O}$ changes by $0.03 \mathrm{~kg} \mathrm{~m}^{-3}$ from a stable surface value $(\sim 10 \mathrm{~m})$ (Weller and Plueddemann, 1996). A stratification index (SI) was also calculated as the seawater density difference (between 10 to $60 \mathrm{~m}$ ) normalized to the equivalent difference in depth.

Water samples from the surface layer $(<10 \mathrm{~m})$ were collected $(0.5-1.5 \mathrm{~L})$ for the determination of fluorometric chlorophyll $a\left(\mathrm{Chl} a_{\mathrm{f}}\right)$, accessory pigments, nutrients, particulate organic carbon (POC), and nitrogen (PON) analysis, and for primary production measurements. Filters for Chl $a_{\mathrm{f}}$ measurements were immediately put in scintillation vials containing $10 \mathrm{~mL}$ of $90 \%$ acetone, which were placed into a $-20^{\circ} \mathrm{C}$ freezer and extracted in the dark for $24 \mathrm{~h}$. Samples for detailed pigment analysis were filtered onto $25 \mathrm{~mm}$ glass fibre filters (GF/F Whatman Inc., Clifton, New Jersey), im- mediately flash frozen in liquid nitrogen, and kept frozen in a freezer (at $-80^{\circ} \mathrm{C}$ ) until analysis in the BIO (2005-2013) or National Oceanography Centre (UK) (2014) laboratories within 2-3 months of collection. Volumes of water sampled for pigment analysis were adjusted, such that samples were filtered as quickly as possible $(<10 \mathrm{~min})$. Nutrient samples were kept refrigerated at $5{ }^{\circ} \mathrm{C}$ and analysed at sea (within $12 \mathrm{~h}$ of collection) on a SEAL AutoAnalyser III. Samples for POC and PON were filtered $(0.25-1 \mathrm{~L})$ onto $25 \mathrm{~mm}$ precombusted $\left(400^{\circ} \mathrm{C}, 12 \mathrm{~h}\right) \mathrm{GF} / \mathrm{F}$ filters, frozen $\left(-20^{\circ} \mathrm{C}\right)$, and returned to the $\mathrm{BIO}$ laboratory for later analysis.

\subsection{Biogeochemical analysis}

Chlorophyll $a$ concentrations were determined fluorometrically after $24 \mathrm{~h}$ of extraction in $90 \%$ acetone on board using a Turner Designs fluorometer (Holm-Hansen et al., 1965). Back in the laboratory, POC / PON samples were oven dried $\left(60^{\circ} \mathrm{C}\right)$ for $8-12 \mathrm{~h}$, stored in a dessicator, pelletized in precombusted tin foil cups and analysed using a PerkinElmer 2400 series CHNS/O analyser, as described in Pepin and Head (2009).

\subsection{Pigment analysis}

Pigments (chlorophyll $a$ and accessory pigments) were quantified using reverse-phase, high-performance liquid chromatography (HPLC). Methods for 2005-2013 (Hudson cruises), including information about the standards, calibration, and quantification procedures are described in detail in Stuart and Head (2005), known as the "BIO method". Methods for samples collected in 2014 (JR302 cruise) are described in Poulton et al. (2006). Quality control of both methods was applied according to Aiken et al. (2009). Precision of the instruments was tested by running samples and standards and the coefficient of variation for pigments were $<10 \%$ of the mean. Limits of detection were $\sim 0.01$ and $0.002 \mathrm{mg} \mathrm{m}^{-3}$ for carotenoids and chlorins, respectively (E. J. H. Head, personal communication, 2016; Poulton et al., 2006). Pigment concentrations below detection limits were not reported. A list of pigments identified and quantified for this study is included in Table 2.

\subsection{CHEMTAX analysis}

The CHEMTAX software (Mackey et al., 1996) was used to estimate the relative abundance of distinct micro-algal groups to total chlorophyll $a$ from in situ pigment measurements. The software utilizes a factorization program that uses "best guess" ratios of accessory pigments to chlorophyll $a$ that are derived for different groups from the literature available and marker pigment concentrations of algal groups that are known to be present in the study area, as reported in Fragoso et al. (2016). The program uses the steepest descent algorithm to obtain the best fit to the data based on assumed ratios of pigment to chlorophyll $a$ (for more detail, 
Table 2. List of phytoplankton pigments and their distributions in algae groups; abbreviations and formulas.

\begin{tabular}{|c|c|c|c|}
\hline Abbreviation & Name & Characteristic of the pigment & Present in/index of/formula \\
\hline PSC & Photosynthetic carotenoid & Light harvesting & All algae \\
\hline PPC & Photoprotective carotenoid & Photoprotection & All algae \\
\hline PPP & Photosynthetic pigment & Light harvesting & All algae \\
\hline But-fuco & 19'-butanoyloxyfucoxanthin & PSC & $\begin{array}{l}\text { Prymnesiophytes, chrysophytes, and dinoflag- } \\
\text { ellates type } 2^{\mathrm{a}} \text { (lacking peridinin) }\end{array}$ \\
\hline Hex-fuco & 19'-hexanoyloxyfucoxanthin & PSC & $\begin{array}{l}\text { Major in prymesiophytes and dinoflagellates } \\
\text { type } 2^{\mathrm{a}} \text { (lacking peridinin) }\end{array}$ \\
\hline Allo & Alloxanthin & PPC & Cryptophytes \\
\hline$\alpha$-Car & $\alpha$-carotene & PPC & $\begin{array}{l}\text { Dominant in prochlorophytes, rhodophyte, and } \\
\text { cryptophyte }\end{array}$ \\
\hline$\beta$-Car & $\beta$-carotene & PPC & $\begin{array}{l}\text { Dominant in cyanobacteria, prochlorophytes, } \\
\text { chlorophytes, prasinophytes, euglenophytes, } \\
\text { and diatoms }\end{array}$ \\
\hline Chl $b$ & Chlorophyll $b$ & PPP & Chlorophytes, prasinophytes, euglenophytes \\
\hline Chl $c_{1}+c_{2}$ & Chlorophyll $c_{1}+c_{2}$ & PPP & $\begin{array}{l}\text { Diatoms, prymnesiophytes, dinoflagellates, } \\
\text { cryptophytes, chrysophytes, and raphidophytes }\end{array}$ \\
\hline $\mathrm{Chl} c_{3}$ & Chlorophyll $c_{3}$ & PPP & $\begin{array}{l}\text { Prymnesiophytes, chrysophytes and dinoflagel- } \\
\text { lates type } 2^{\mathrm{a}} \text { (lacking peridinin) }\end{array}$ \\
\hline Chlide $a$ & Chlorophyllide $a$ & Degradation product of Chl $a_{\mathrm{HPLC}}$ & Senescent phytoplankton \\
\hline DD & Diadinoxanthin & PPC & $\begin{array}{l}\text { Diatoms, prymnesiophytes, dinoflagellates, } \\
\text { chrysophytes, and raphidophytes }\end{array}$ \\
\hline DT & Diatoxanthin & PPC & $\begin{array}{l}\text { Diatoms, prymnesiophytes, dinoflagellates, } \\
\text { chrysophytes, and raphidophytes }\end{array}$ \\
\hline Fuco & Fucoxanthin & PSC & $\begin{array}{l}\text { Diatoms, prymnesiophytes, chrysophytes, } \\
\text { pelagophytes, and dinoflagellates type } 2^{\text {a }} \\
\text { (lacking peridinin) }\end{array}$ \\
\hline Chl $a_{\text {HPLC }}$ & HPLC-derived chlorophyll $a$ & PPP & All phytoplankton except Prochlorococcus \\
\hline Peri & Peridinin & PSC & Dinoflagellates type $1^{\mathrm{a}}$ \\
\hline Pras & Prasinoxanthin & PPC & Prasinophytes type $1^{\mathrm{b}}$ \\
\hline Viola & Violaxanthin & PPC & $\begin{array}{l}\text { Chlorophytes, prasinophytes, and eustigmato- } \\
\text { phytes }\end{array}$ \\
\hline Zea + Lut & Zeaxanthin + lutein & PPC & $\begin{array}{l}\text { Cyanobacteria, Prochlorococcus, chlorophytes, } \\
\text { and prasinophytes type } 2^{\text {b }}\end{array}$ \\
\hline TChl $a$ & Total chlorophyll $a$ derived from HPLC analysis & & Chl $a_{\text {HPLC }}+$ Chlide $a$ \\
\hline $\mathrm{TC}$ & Total carotenoids & Include all carotenoids & $\begin{array}{l}\text { But-fuco }+ \text { Hex-fuco }+ \text { Allo }+\alpha \text {-Car }+\beta \text {-Car } \\
+ \text { DD }+ \text { DT }+ \text { Fuco }+ \text { Peri }+ \text { Pras }+ \text { Viola }+ \\
\text { Zea }+ \text { Lut }\end{array}$ \\
\hline AP & Accessory pigments & Include all pigments except $\mathrm{TChl} a$ & $\mathrm{TC}+\mathrm{Chl} b+\mathrm{Chl} c_{1}+c_{2}+\mathrm{Chl} c_{3}$ \\
\hline
\end{tabular}

According to Jeffrey et al. (1997) or ${ }^{\text {a }}$ Higgins et al. (2011) or ${ }^{\text {b }}$ Vidussi et al. (2004).

see Mackey et al., 1996). Because CHEMTAX is sensitive to the seed values of the initial ratio matrix (Latasa, 2007), we used a later version (v1.95) to obtain the more stable output matrices. In this CHEMTAX version, the initial matrices are optimized by generating 60 further pigment ratio tables using a random function (RAND in Microsoft Excel) as described in Wright et al. (2009). The results of the six best output matrices (with the smallest residuals, equivalent to $10 \%$ of all matrices) were used to calculate the averages of the abundance estimates and final pigment ratios.

One of the main assumptions of the CHEMTAX method is that information about the phytoplankton taxonomy is used to assure that the pigment ratios are applied and interpreted correctly (Irigoien et al., 2004). To satisfy this requirement, initial pigment ratios were carefully selected and applied to each cluster to adjust the pigments to the appropriate groups, according to previous microscopic observations (Fragoso et al., 2016) and literature information (see Table 3). Pigment ratio tables were based on the literature in waters having comparable characteristics to the Labrador Sea, such as Baffin Bay (Vidussi et al., 2004), the Beaufort Sea (Coupel et al., 2015), and the North Sea (Antajan et al., 2004; Muylaert et al., 2006) or from surface (high light) field data (Higgins et al., 2011) (Table 3). High light field ratios were chosen because samples were collected from surface waters during May and June, when photosynthetic active radiation (PAR) was high (daily incident irradiance averaged per month $>30 \mathrm{~mol} \mathrm{PAR} \mathrm{m}^{-2} \mathrm{~d}^{-1}$, Harrison et al., 2013). The pigments chosen for CHEMTAX analysis were: 19-butanoyloxyfucoxanthin (But-fuco), 19-hexanoyloxyfucoxanthin (Hex-fuco), alloxanthin (Allo), total chlorophyll $a$ derived from HPLC analysis (TChl $a$, see Table 2), chlorophyll $b(\mathrm{Chl} b)$, chlorophyll $c 3\left(\mathrm{Chl} c_{3}\right)$, fucoxanthin (Fuco), peridinin (Peri), prasinoxanthin (Pras), and zeaxanthin + lutein (Zea + Lut). Zeaxanthin (Zea) and lutein (Lut) are two different pigments that co-eluted as a sin- 
gle peak by the methods of pigment analyses applied in this study.

The other main requirement of the CHEMTAX method is that pigment ratios remain constant across the subset of samples that are being analysed (Mackey et al., 1996). To satisfy this assumption, a priori analysis was performed, where pigment data were sub-divided into groups using cluster analysis (Bray-Curtis similarity; PRIMER-e V7, see Sect. 2.7) and each group was processed separately by the CHEMTAX program (Table 3; for the final ratio matrix, see Supplement). This approach was used as distinct phytoplankton communities have been previously observed in the Labrador Sea (Fragoso et al., 2016), so the ratio of accessory pigment to chlorophyll $a$ likely varies within different water masses across the Labrador Sea (LC, IC and WGC). Absolute concentrations of selected pigments (But-fuco, Hex-fuco, Allo, $\mathrm{Chl} b$, Chl $c_{3}$, Fuco, Peri, Pras, and Zea + Lut) were fourthroot transformed and standardized (converted to \%) before being analysed. Due to the high abundance of diatoms in the data, we decided to apply a fourth-root transformation to increase the importance of less abundant groups, which would allow us to better discern the spatial-temporal patterns of the phytoplankton communities in the Labrador Sea.

An initial cluster analysis on the select pigment data identified five major groups having $60 \%$ similarity between samples. Clusters included stations partially located: (1) on the shelves, where Fuco dominated at a few stations (I); (2) in the eastern part of the Labrador Sea, where most stations had high relative concentrations of Fuco and $\mathrm{Chl} c_{3}$ (II); (3) in the central Labrador Sea, where a few stations had high proportions of Fuco, Hex-fuco, and Peri (III); (4) on the western part of the section, where $\mathrm{Chl} b$ and Fuco were the main pigments at most stations (IV); and (5) in the central Labrador Sea, where most stations had a mixture of pigments (Fuco, $\mathrm{Chl} c_{3}$, Hex-fuco, Chl $b$, Peri, and others) (V) (Fig. S1, Supplement).

Prasinophytes were separated into "prasinophyte type 1", which contains Pras, and "prasinophyte type 2", such as Pyramimonas and Micromonas, with the latter previously found lacking Pras and containing Zea + Lut in the North Water Polynya (Canadian Arctic) (see Vidussi et al., 2004). Both genera were observed in light microscope counts in Labrador Sea samples (G. M. Fragoso, personal observation, 2015), M. pusilla has been observed in the Beaufort Sea (Coupel et al., 2015), and was found to be one of the main pico-eukaryotes in the North Water Polynya from April to July of 1998 (Lovejoy et al., 2002). Zea is not only found in "prasinophytes type 2", but is also the major accessory pigment of cyanobacteria (such as Synechococcus spp.), which have been observed in the Labrador Sea (particularly in Atlantic waters; Li et al., 2006). Zea is also a minor pigment in chlorophytes, while Lut is often the dominant carotenoid in this group (MacIntyre et al., 2010; Vidussi et al., 2004). Due to their association with the warmer Atlantic waters, cyanobacteria were assumed to be absent from very cold wa- ters, such as the Labrador Current (see Fragoso et al., 2016). Prasinophytes contain $\mathrm{Chl} b$, as well as chlorophytes (Vidussi et al., 2004) which were observed in large numbers with the microscope (G. M. Fragoso, personal observation, 2015). Dinoflagellates were separated into species that contain Peri (Heterocapsa sp. and Amphidium; Coupel et al., 2015; Higgins et al., 2011), and those that do not (Gymnodinium spp.; herein defined as "dinoflagellates type-2" (Dino-2) according to Higgins et al., 2011) and may contain $\mathrm{Chl} c_{3}$, But-fuco, Hex-fuco, and Fuco. Dinoflagellates were observed in lower concentrations in the eastern Labrador Sea (Fragoso et al., 2016), so that "Dino-2" was assumed absent from this area (clusters I and II in Table 3). Cryptophytes (Table 3) are the only group to contain Allo.

Prymnesiophytes were divided into three groups: (1) Phaeocystis pouchetii, which was observed in high concentrations in the eastern Labrador Sea (Fragoso et al., 2016) (clusters I and II, Table 3); (2) "Prymnesiophyte 1" (as in Vidussi et al., 2004), associated with Chrysochromulina spp. and observed in the western Labrador Sea (Labrador Current, this study) (cluster IV, Table 3); and (3) "HAPTO-6" (as in Higgins et al., 2011), which included the coccolithophores, particularly Emiliania huxleyi associated with Atlantic waters (central-eastern region of the Labrador Sea) (clusters I, II, III and V, Table 3). Phaeocystis pouchetii occurred in waters having low Hex-fuco and But-fuco concentrations and high $\mathrm{Chl} c_{3}$ and Fuco concentrations (cluster II, Fig. S1, Supplement). Similar pigment compositions were found in Phaeocystis globosa blooms in Belgian Waters (Antajan et al., 2004; Muylaert et al., 2006) and high ratios of $\mathrm{Chl} c_{3}$ to Chl $a_{\text {HPLC }}$ (HPLC-derived chlorophyll $a$ ) have been used to identify Phaeocystis pouchetii in the Labrador Sea (see Stuart et al., 2000). Thus, $\mathrm{Chl} c_{3}$ and Fuco were the only pigments that could be used to represent Phaeocystis. In addition to $\mathrm{Chl} c_{3}$ and Fuco, "Prymnesiophyte 1" included Hex-fuco, while "HAPTO-6" included Hex-fuco and But-fuco as in Higgins et al. (2011). Chrysophytes and pelagophytes (such as Dictyocha speculum) have high ratios of But-fuco to Chl $a_{\mathrm{HPLC}}$ (Coupel et al., 2015; Fragoso and Smith, 2012), and finally diatoms were identified as containing high Fuco: Chl $a_{\text {HPLC }}$ ratios (Vidussi et al., 2004) (Table 3).

\subsection{Photosynthesis versus irradiance incubations}

Water samples were spiked with ${ }^{14} \mathrm{C}$ bicarbonate and incubated in a light box under 30 different irradiance levels (from $1-600 \mathrm{~W} \mathrm{~m}^{-2}$ ) at in situ temperature for 2 to $3 \mathrm{~h}$ to measure parameters derived from photosynthesis versus irradiance (P-E) curves as described by Stuart et al. (2000). Measurements were fitted to the equation of Platt and Gallegos (1980) to determine photosynthetic efficiency $\left(\alpha^{\mathrm{B}}\right)$, the maximum photosynthetic rate normalized to chlorophyll biomass $\left(P_{\mathrm{m}}^{\mathrm{B}}\right)$, the light intensity approximating the onset of satura- 
Table 3. Initial ratio matrix of accessory pigment to chlorophyll $a$ for distinct algal groups for each cluster group. * Rf refers to the literature where the pigment ratios were extracted. See explanation of each group in the methods section.

\begin{tabular}{|c|c|c|c|c|c|c|c|c|c|c|c|}
\hline \multirow{2}{*}{$\begin{array}{l}\text { Region } \\
\text { Group/pigment }\end{array}$} & \multicolumn{11}{|c|}{ I and II (eastern Labrador Sea) } \\
\hline & $\mathrm{Chl} b$ & $\mathrm{Chl} c_{3}$ & Fuco & Peri & $\mathrm{Zea}+\mathrm{Lut}$ & Allo & But-fuco & Hex-fuco & Pras & TChl $a$ & $\mathrm{Rf}^{*}$ \\
\hline Prasinophyte 1 & 0.512 & 0 & 0 & 0 & 0 & 0 & 0 & 0 & 0.075 & 1 & 2 \\
\hline Prasinophyte 2 & 0.738 & 0 & 0 & 0 & 0.008 & 0 & 0 & 0 & 0 & 1 & 2 \\
\hline CHLORO-1 & 0.339 & 0 & 0 & 0 & 0.047 & 0 & 0 & 0 & 0 & 1 & 4 \\
\hline Dinoflagellates & 0 & 0 & 0 & 0.600 & 0 & 0 & 0 & 0 & 0 & 1 & 5 \\
\hline Cryptophytes & 0 & 0 & 0 & 0 & 0 & 0.673 & 0 & 0 & 0 & 1 & 2 \\
\hline Phaeocystis & 0 & 0.208 & 0.350 & 0 & 0 & 0 & 0 & 0 & 0 & 1 & 1 \\
\hline НАРТО-6 & 0 & 0.155 & 0.195 & 0 & 0 & 0 & 0.019 & 1.054 & 0 & 1 & 4 \\
\hline Chryso/pelagophyte & 0 & 0.114 & 0.398 & 0 & 0 & 0 & 0.595 & 0 & 0 & 1 & 2 \\
\hline Cyanobacteria & 0 & 0 & 0 & 0 & 0.232 & 0 & 0 & 0 & 0 & 1 & 3 \\
\hline Diatoms & 0 & 0 & 1.229 & 0 & 0 & 0 & 0 & 0 & 0 & 1 & 2 \\
\hline Region & \multicolumn{11}{|c|}{ III and V (central Labrador Sea) } \\
\hline Group/pigment & Chl $b$ & $\mathrm{Chl} c_{3}$ & Fuco & Peri & Zea + Lut & Allo & But-fuco & Hex-fuco & Pras & TChl $a$ & $\mathrm{Rf}^{*}$ \\
\hline Prasinophyte 1 & 0.512 & 0 & 0 & 0 & 0 & 0 & 0 & 0 & 0.075 & 1 & 2 \\
\hline Prasinophyte 2 & 0.738 & 0 & 0 & 0 & 0.008 & 0 & 0 & 0 & 0 & 1 & 2 \\
\hline CHLORO-1 & 0.339 & 0 & 0 & 0 & 0.047 & 0 & 0 & 0 & 0 & 1 & 4 \\
\hline Dinoflagellates & 0 & 0 & 0 & 0.600 & 0 & 0 & 0 & 0 & 0 & 1 & 5 \\
\hline Dino-2 & 0 & 0.179 & 0.300 & 0 & 0 & 0 & 0.081 & 0.194 & 0 & 1 & 4 \\
\hline Cryptophytes & 0 & 0 & 0 & 0 & 0 & 0.673 & 0 & 0 & 0 & 1 & 2 \\
\hline HAPTO-6 & 0 & 0.155 & 0.195 & 0 & 0 & 0 & 0.019 & 1.054 & 0 & 1 & 4 \\
\hline Chryso/Pelagophyte & 0 & 0.114 & 0.398 & 0 & 0 & 0 & 0.595 & 0 & 0 & 1 & 2 \\
\hline Cyanobacteria & 0 & 0 & 0 & 0 & 0.232 & 0 & 0 & 0 & 0 & 1 & 3 \\
\hline Diatoms & 0 & 0 & 1.229 & 0 & 0 & 0 & 0 & 0 & 0 & 1 & 2 \\
\hline Region & \multicolumn{11}{|c|}{ IV (western Labrador Sea) } \\
\hline Group/pigment & $\mathrm{Chl} b$ & $\mathrm{Chl} c_{3}$ & Fuco & Peri & Zea + Lut & Allo & But-fuco & Hex-fuco & Pras & TChl $a$ & $\mathrm{Rf}^{*}$ \\
\hline Prasinophyte 1 & 0.512 & 0 & 0 & 0 & 0 & 0 & 0 & 0 & 0.075 & 1 & 2 \\
\hline Prasinophyte 2 & 0.738 & 0 & 0 & 0 & 0.008 & 0 & 0 & 0 & 0 & 1 & 2 \\
\hline CHLORO-1 & 0.339 & 0 & 0 & 0 & 0.047 & 0 & 0 & 0 & 0 & 1 & 4 \\
\hline Dino-2 & 0 & 0.179 & 0.300 & 0 & 0 & 0 & 0.081 & 0.194 & 0 & 1 & 4 \\
\hline Dinoflagellates & 0 & 0 & 0 & 0.600 & 0 & 0 & 0 & 0 & 0 & 1 & 5 \\
\hline Cryptophytes & 0 & 0 & 0 & 0 & 0 & 0.673 & 0 & 0 & 0 & 1 & 2 \\
\hline Prymnesiophyte 1 & 0 & 0.038 & 0.416 & 0 & 0 & 0 & 0 & 1.108 & 0 & 1 & 2 \\
\hline Chryso/Pelagophyte & 0 & 0.114 & 0.398 & 0 & 0 & 0 & 0.595 & 0 & 0 & 1 & 2 \\
\hline Diatoms & 0 & 0 & 1.229 & 0 & 0 & 0 & 0 & 0 & 0 & 1 & 2 \\
\hline
\end{tabular}

${ }^{1}$ Antajan et al. (2004), ${ }^{2}$ Vidussi et al. (2004), ${ }^{3}$ Muylaert et al. (2006), ${ }^{4}$ Higgins et al. (2011), ${ }^{5}$ Coupel et al. (2015)

tion $\left(E_{k}\right)$, the saturation irradiance $\left(E_{\mathrm{s}}\right)$, and the photoinhibition parameter $(\beta)$.

\subsection{Statistical analysis}

Fragoso et al. (2016) found a significant linear relationship between phytoplankton carbon, calculated from phytoplankton cell counts, and POC data using results from 2011-2014 surveys in the Labrador Sea (i.e. $\mathrm{POC}=1.01 \quad \mathrm{POC}_{\text {phyto }}+240.92 ; r^{2}=0.47 ; n=44$; $p<0.0001)$. To estimate phytoplankton-derived carbon ( POC $_{\text {phyto }}$ ) concentrations (as opposed to total POC, which includes detritus and heterotrophic organisms), regression analysis was performed using the carbon calculated from cell counts (derived from Fragoso et al., 2016) and measurements of fluorometric chlorophyll $a\left(\mathrm{Chl} a_{\mathrm{f}}\right)$. This regression $\left(\mathrm{POC}_{\text {phyto }}=38.9 \mathrm{Chl} a_{\mathrm{f}} ; r^{2}=0.9 ; n=41 ; p<0.0001\right)$ was then applied to estimate $\mathrm{POC}_{\text {phyto }}$ for stations where phytoplankton cell counts were not available (2005-2010).

Phytoplankton community structure derived from pigment concentrations was investigated using PRIMER-E (v7) software (Clarke and Warwick, 2001). Chlorophyll $a$ concentrations derived for each algal group resulting from CHEMTAX analysis were standardized (converted to percentage values) 
to obtain their relative proportions, which were fourth-root transformed to allow the least abundant groups to contribute to the analysis. Similarity matrices were generated from Bray-Curtis similarity for cluster analysis. A SIMPER (SIMilarity PERcentages) routine with a cut-off of $90 \%$ cumulative contribution to the similarity was used to reveal the contributions of each group to the overall similarity within clusters. One-way ANOSIM was also applied to determine whether taxonomic compositions of the clusters were significantly different.

A redundancy analysis (RDA) using the CANOCO 4.5 software (CANOCO, Microcomputer Power, Ithaca, NY) was performed to analyse the effects of different environmental factors on the Labrador Sea phytoplankton community structure (see also Fragoso et al., 2016). Data were log-transformed and forward-selection (a posteriori analysis) identified the subset of environmental variables that significantly explained the taxonomic distribution and community structure when analysed individually ( $\lambda_{1}$, marginal effects) or when included in a model where other forward-selected variables were analysed together $\left(\lambda_{\mathrm{a}}\right.$, conditional effects). A Monte Carlo permutation test ( $n=999$, reduced model) was applied to test the statistical significance $(p<0.05)$ of each of the forward-selected variables.

\section{Results}

\subsection{Environmental variables}

Sampling dates varied from May to June during this 10year study, where samples from 2007, 2011 and 2013 were collected in early May, as opposed to samples from 2012 and 2104, which were collected later in the season (midto late June) (Fig. 2b). Environmental parameters, as well as fluorometric chlorophyll $a\left(\mathrm{Chl} a_{\mathrm{f}}\right)$ concentrations varied noticeably along the southwest-northeast section of the Labrador Sea (Fig. 2c-1). The shelf and slope regions (LSh, $\mathrm{LSl}, \mathrm{GSl}, \mathrm{GSh})$ had colder and fresher waters $\left(<3^{\circ} \mathrm{C}\right.$ and $<33.5$, respectively) compared to the central basin (CB), where surface waters were saltier $(>33.5)$ and warmer $\left(>3{ }^{\circ} \mathrm{C}\right)$, particularly in $2005,2006,2012$, and $2014\left(>5^{\circ} \mathrm{C}\right)$ (Fig. 2c, d). Shelf waters that were the coldest and freshest were also the most highly stratified ((stratification index (SI) $>5 \times 10^{-3} \mathrm{~kg} \mathrm{~m}^{-4}$ ), particularly on the Labrador Shelf (SI $>15 \times 10^{-3} \mathrm{~kg} \mathrm{~m}^{-4}$ ), whereas waters from the CB were less stratified ( $\mathrm{SI}<5 \times 10^{-3} \mathrm{~kg} \mathrm{~m}^{-4}$ ), apart from at stations collected later in the season (Fig. 2b), where waters were slightly warmer than usual $\left(>5^{\circ} \mathrm{C}\right)$ in 2005,2012 , and 2014 (Fig. 2e). Chl $a_{\mathrm{f}}$ concentrations were highest (>4 mg Chl $a_{\mathrm{f}}$ $\mathrm{m}^{-3}$ ) at stations where waters were highly stratified, particularly on the shelves (Fig. 2f). Nitrate, phosphate, and silicate concentrations were inversely related to $\mathrm{Chl} a_{\mathrm{f}}$ concentration, being lowest $\left(<5,0.5\right.$, and $3 \mu \mathrm{mol} \mathrm{L}{ }^{-1}$, respectively) on the shelves, and during some years in the CB (e.g. 2012), where blooms formed (Fig. 2f-i). POC: PON ratios were $>8$ at most stations in shelf and slope waters and at a few stations in the CB during 2009 and 2011 (Fig. 2j). Shelf waters mostly had higher silicate : nitrate $\left(\mathrm{Si}(\mathrm{OH})_{4}: \mathrm{NO}_{3}^{-}\right)$ratios $(>1)$ than the CB, particularly in the LSh (Fig. 2k). Labrador Sea surface waters usually had nitrate : phosphate $\left(\mathrm{NO}_{3}^{-}: \mathrm{PO}_{4}^{3-}\right)$ less than 16 , although $\mathrm{NO}_{3}^{-}: \mathrm{PO}_{4}^{3-}$ were relatively higher in the $\mathrm{CB}$ than in the shelf regions ( $>10$ ) (Fig. 2l).

\subsection{CHEMTAX interpretation and group distributions}

Diatoms were the most abundant phytoplankton group found in the Labrador Sea, particularly at some stations on the shelves where they dominated almost $100 \%$ of the total phytoplankton community (Fig. 3a). Chlorophytes and prasinophytes were common in the central-western part (Fig. 3b, c), whereas Phaeocystis was highest at the eastern part of the Labrador Sea (Fig. 3d). Dinoflagellates were abundant in the central region of the Labrador Sea (Fig. 3e). Other prymnesiophytes, including coccolithophores and Chrysochromulina, were also common in the central part of the Labrador Sea (Fig. 3f). Overall, chrysophytes and pelagophytes were found in low abundances in the Labrador Sea, except at the central region of the Labrador Sea during 2011 (Fig. 3g). Cyanobacteria were most abundant at the Labrador Slope and Greenland Shelf, and during some years (2005 and 2012) in the central Labrador Sea (Fig. 3h). Cryptophytes comprised less than $10 \%$ of total phytoplankton chlorophyll concentrations (data not shown).

A cluster analysis of algal groups derived from CHEMTAX results revealed clusters of stations at various similarity levels (Fig. 4). Pairwise one-way analysis of similarity (ANOSIM) between clusters suggested that they were significantly different in terms of algal pigment composition $(p=0.001)$. However, pairwise analysis of clusters C3a and $\mathrm{C} 3 \mathrm{~b}$ showed that these groups were more similar in composition ( $\mathrm{R}$ statistic of 0.33 ) than other clusters (R statistic values approached 1) (see Clarke and Warwick, 2001). The first division occurred at $61 \%$, separating three main clusters (A, B, and C) (Fig. 4a). Cluster $\mathrm{C}$ was subdivided at $65 \%$ resulting in clusters $\mathrm{C} 1, \mathrm{C} 2$, and $\mathrm{C} 3$ (Fig. 4a). A third division (similarity of $73 \%$ ) occurred at cluster $\mathrm{C} 3$ resulting in two other clusters $\mathrm{C} 3 \mathrm{a}$ and $\mathrm{C} 3 \mathrm{~b}$ (Fig. 4a). Overall, six functional clusters (A, B, C1, C2, C3a, and C3b) represented the distinct phytoplankton communities occurring in the Labrador Sea (Fig. 4a). These communities generally occupied different regions of the Labrador Sea, namely the Labrador Shelf/Slope (west, Cluster C1 and, mainly, Cluster $\mathrm{C} 3 \mathrm{a}$ ), the Central Basin (middle, mainly Clusters $\mathrm{C} 2$ or $\mathrm{C} 3 \mathrm{~b}$ ), and the Greenland Shelf/Slope (east, mainly Clusters C3a, A, B) (Fig. 4b, c).

Chl $a_{\mathrm{f}}$ concentrations were high at stations where diatoms were dominant (Fig. 4b, c). Diatoms were the most abundant phytoplankton group in Labrador Sea waters, particularly at stations on the shelves, where communities were 


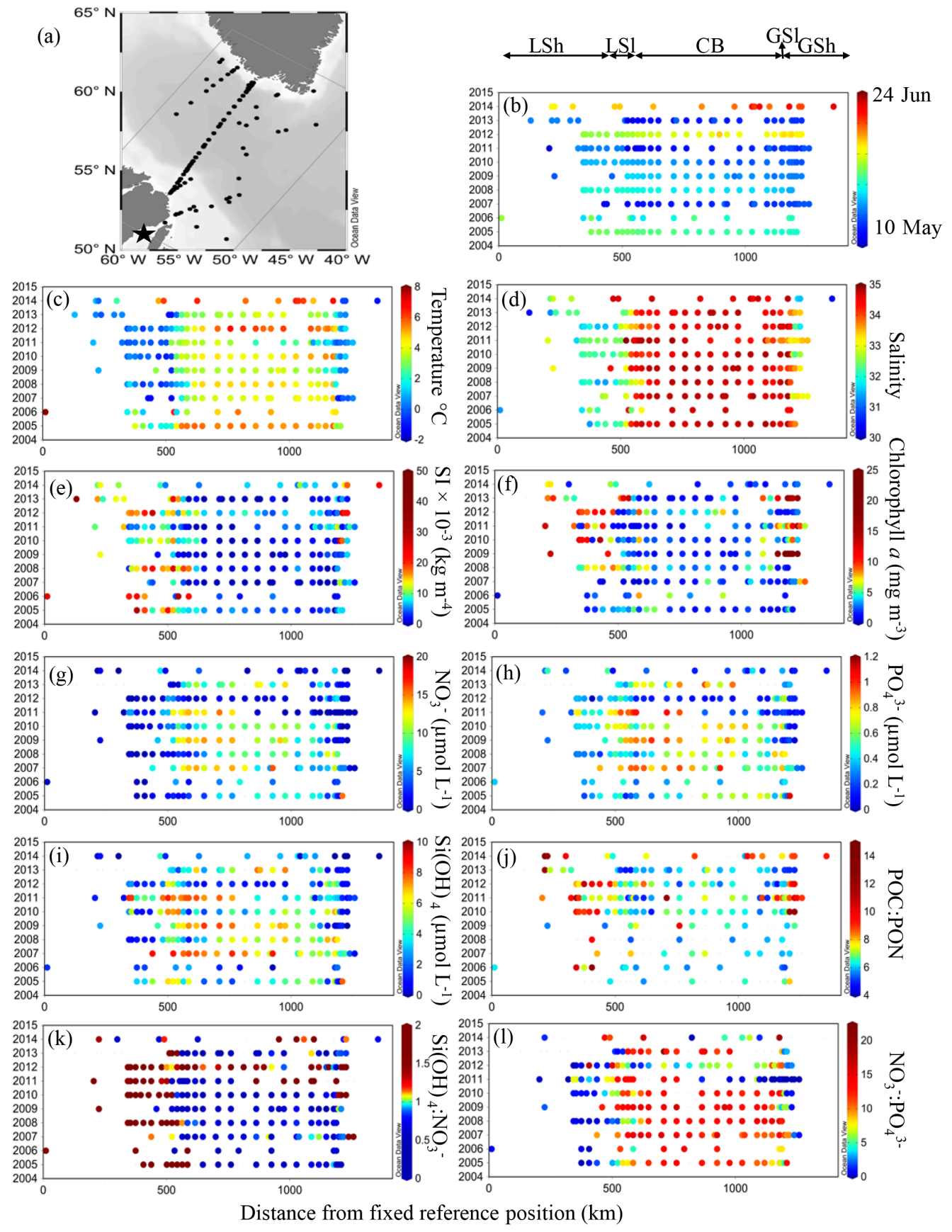

Figure 2. Map with sampling stations and distances from a fixed reference position (Northeast Gulf of St Lawrence) in the $x$ axis shown by the star (a). Values are given at individual stations sampled between 2005 and 2014 ( $y$ axis) for the following variables: date of sample collection (b), temperature (c), salinity (d), stratification index (SI) (e), chlorophyll $a$ (f), nitrate $\left(\mathrm{NO}_{3}^{-}\right)(\mathbf{g})$, phosphate $\left(\mathrm{PO}_{4}^{3-}\right)(\mathbf{h})$, silicate $\left(\mathrm{Si}(\mathrm{OH})_{4}\right)$ concentrations (i), ratios of particulate organic carbon (POC) to particulate organic nitrogen $(\mathrm{PON})(\mathbf{j})$, silicate to nitrate $\left(\mathrm{Si}(\mathrm{OH})_{4}: \mathrm{NO}_{3}^{-}\right)$ ratios (k), and nitrate to phosphate $\left(\mathrm{NO}_{3}^{-}: \mathrm{PO}_{4}^{3-}\right)$ ratios (l). LSh, Labrador Shelf; LSl, Labrador Slope; CB, Central Basin; GSl, Greenland Slope; GSh, Greenland Shelf.

sometimes composed of almost $100 \%$ diatoms (clusters A and C1) (Fig. 4b, c). Diatoms were also abundant at (or near to) the Greenland Shelf, where Phaeocystis was co-dominant (cluster B) and at (or near to) the Labrador Shelf in the west section, where chlorophytes were the second most abundant group (cluster C3a). Likewise, diatoms were dominant in the central Labrador Sea in some years (2008, 2012, and 2014 , cluster C2), where dinoflagellates were also dominant 


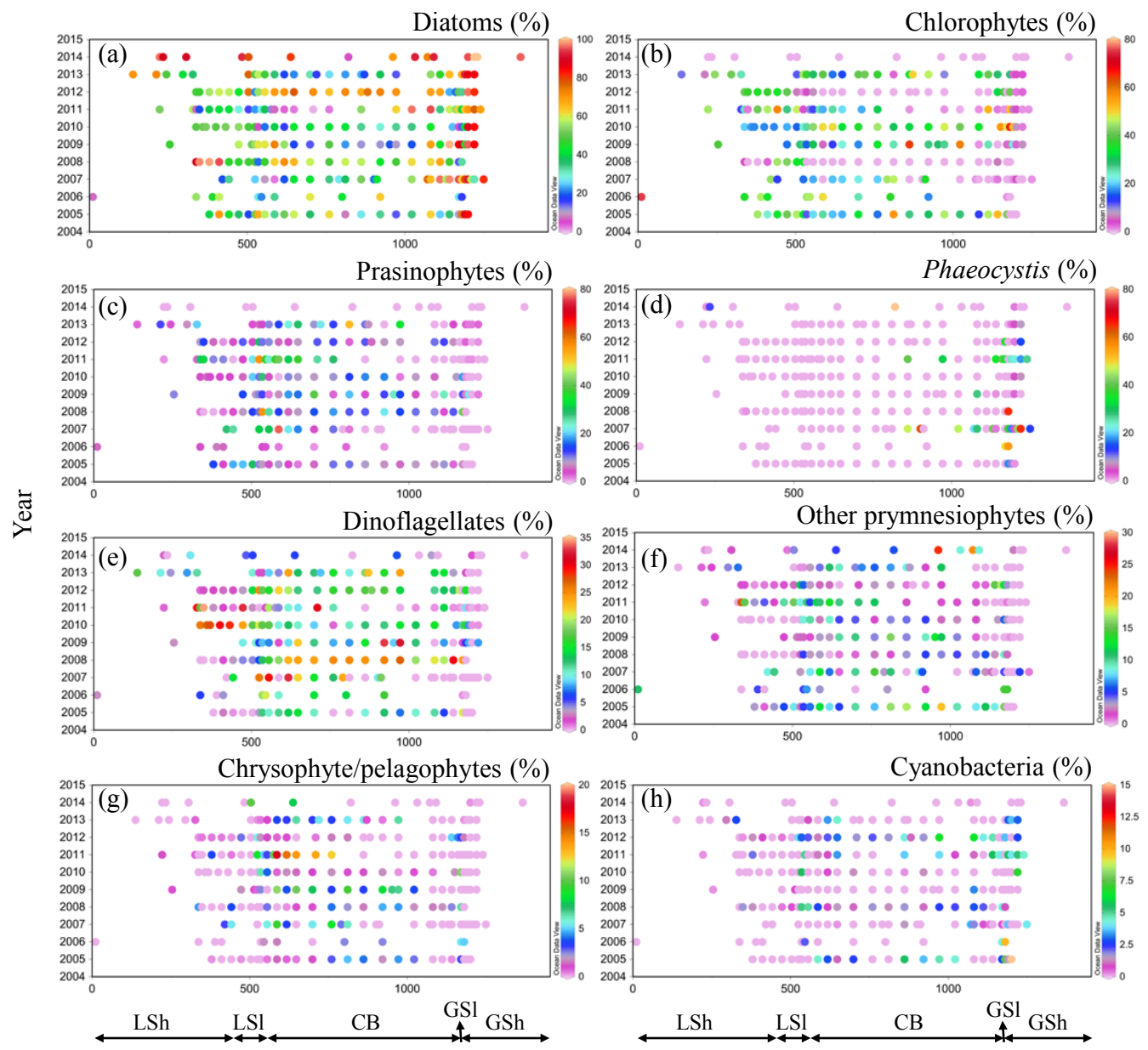

Section distance $(\mathrm{km})$

Figure 3. Relative contribution (\%) of chlorophyll $a$ from distinct phytoplankton groups at each station from 2005 to 2014 along the section distance from Labrador coast represented in Fig. 2a (star symbol). LSh, Labrador Shelf; LSl, Labrador Slope; CB, Centre Basin; GSl, Greenland Slope; GSh, Greenland Shelf. Note the distinct scales for each group.

(Fig. 4b, c). Most stations in the central basin had low Chl $a_{\mathrm{f}}$ concentrations and high diversity of algal groups (cluster $\mathrm{C} 3 \mathrm{~b}$ ), with mixed assemblages of diatoms, dinoflagellates, and other flagellates (Fig. 4b, c). The positions of oceanographic fronts, usually characterized by sharp transitions in phytoplankton communities, varied from year to year but were generally located near the continental slopes (Fig. 4c).

\subsection{Phytoplankton distributions and environmental controls}

Distributions of surface phytoplankton communities defined above varied according to the water mass distributions across the shelves and central basin of the Labrador Sea. Potential temperatures and salinities also varied among these water masses (Fig. 5a). In general, a community dominated by chlorophytes and diatoms (cluster $\mathrm{C} 3 \mathrm{a}$ ) was associated with the inshore branch of the Labrador Current (LC) on the
Labrador Shelf. Surface waters from the LC were the coldest (temperature $<2{ }^{\circ} \mathrm{C}$ ) and least saline, with the lowest density $\left(\sigma_{O}\right.$ of most stations approximately $<26.5 \mathrm{~kg} \mathrm{~m}^{-3}$ ) of all the surface water masses of the Labrador Sea (Fig. 5a). Mixed assemblages (cluster C3b), as well as blooms (chlorophyll average, $4 \mathrm{mg} \mathrm{Chl} a_{\mathrm{f}} \mathrm{m}^{-3}$ ) of dinoflagellates and diatoms (cluster $\mathrm{C} 2$ ) were associated with the Atlantic water mass, the Irminger Current (IC) (Fig. 5a). These were the warmest (temperature $>3{ }^{\circ} \mathrm{C}$ ), saltiest (salinity $>34$ ), and densest $\left(\sigma_{O}\right.$ of most stations $>27 \mathrm{~kg} \mathrm{~m}^{-3}$ ) surface waters of the Labrador Sea (Fig. 5a). A community dominated by diatoms and Phaeocystis (cluster B) occurred in waters of the West Greenland Current (WGC), which had intermediate temperatures (mostly $0-4{ }^{\circ} \mathrm{C}$ ) and salinities (33-34.5) when compared to those of the LC and IC (Fig. 5a).

Redundancy analysis (RDA) was used to investigate the hydrographic variables that explained the variance (explanatory variables) in the phytoplankton communities identified 


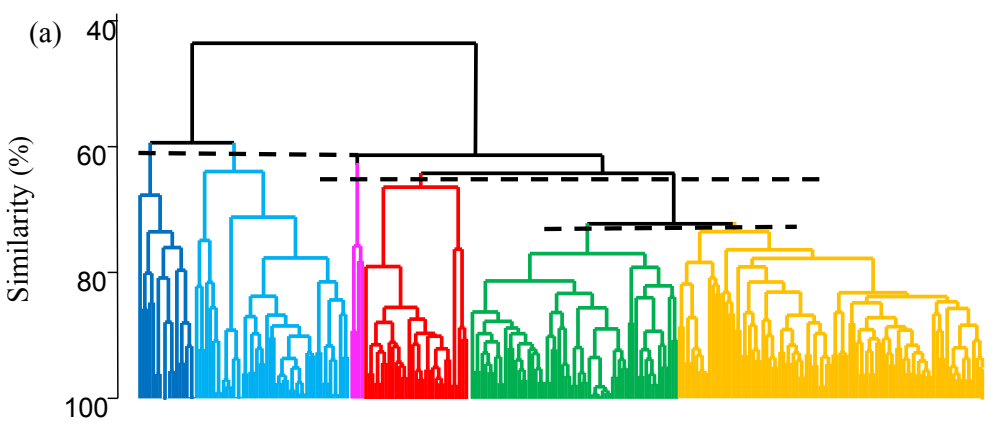

(b)

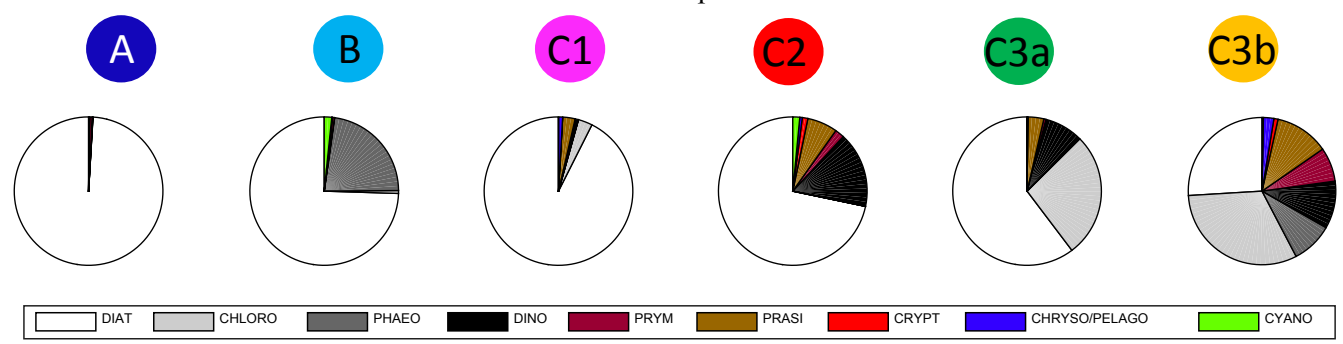

(c)

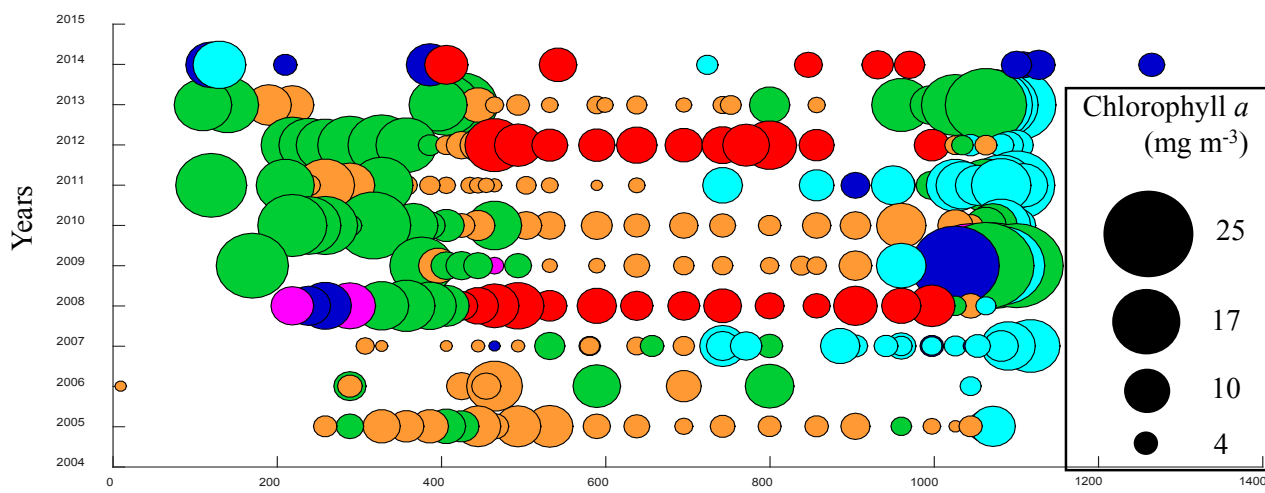

Distance from fixed reference position $(\mathrm{km})$

Figure 4. Dendrogram showing clustering of samples (a) and the proportion of chlorophyll $a$ contributed by each phytoplankton group for each cluster (b). Spatial distribution of distinct phytoplankton communities (cluster groups) along the section, showing the distance from the star in Fig. 2a) (c). Bubble size in (c) represents total chlorophyll $a$ biomass (minimum $0.3 \mathrm{mg} \mathrm{Chl} a_{\mathrm{f} \mathrm{m}} \mathrm{m}^{-3}$ and maximum $25 \mathrm{mg} \mathrm{Chl} a_{\mathrm{f}} \mathrm{m}^{-3}$ ).

from pigment analyses. The ordination diagram revealed that stations from each distinct cluster are concentrated in different quadrants (Fig. 5b), with the arrows in the ordination diagram representing the environmental variables. Positive or negative correlations indicate that the arrows are orientated parallel to the distribution of cluster stations (same direction, positive; opposite direction, negative correlations), with the strength of the correlation proportional to the arrow length. Table 4a indicates that the first axis ( $x$ axis) of the redundancy analysis explained most of the variance $(83.5 \%$ of species-environment relationship; taxa-environmental correlation of 0.68). Summed, the canonical axes explained $99.8 \%$ of the variance (axis $1, p=0.002$; all axes, $p=$
0.002) (Table 4a), which indicates that the environmental variables included in this analysis explained almost $100 \%$ of the variability. Forward selection showed that five of the six environmental factors (silicate, temperature, salinity, nitrate, and phosphate) included in the analysis best explained the variance in phytoplankton community composition when analysed together $(p<0.05$, Table $4 \mathrm{~b})$. When all variables were analysed together (conditional effects, referred to as $\lambda_{\mathrm{a}}$ in Table $4 \mathrm{~b}$ ), silicate concentration was the most significant explanatory variable $\left(\lambda_{\mathrm{a}}=0.2, p=0.001\right)$, followed by temperature $\left(\lambda_{\mathrm{a}}=0.05, p=0.001\right)$, salinity $\left(\lambda_{\mathrm{a}}=0.02\right.$, $p=0.002)$, nitrate concentration $\left(\lambda_{\mathrm{a}}=0.01, p=0.016\right)$ and phosphate concentration $\left(\lambda_{\mathrm{a}}=0.02, p=0.002\right)$ (Table 4). 

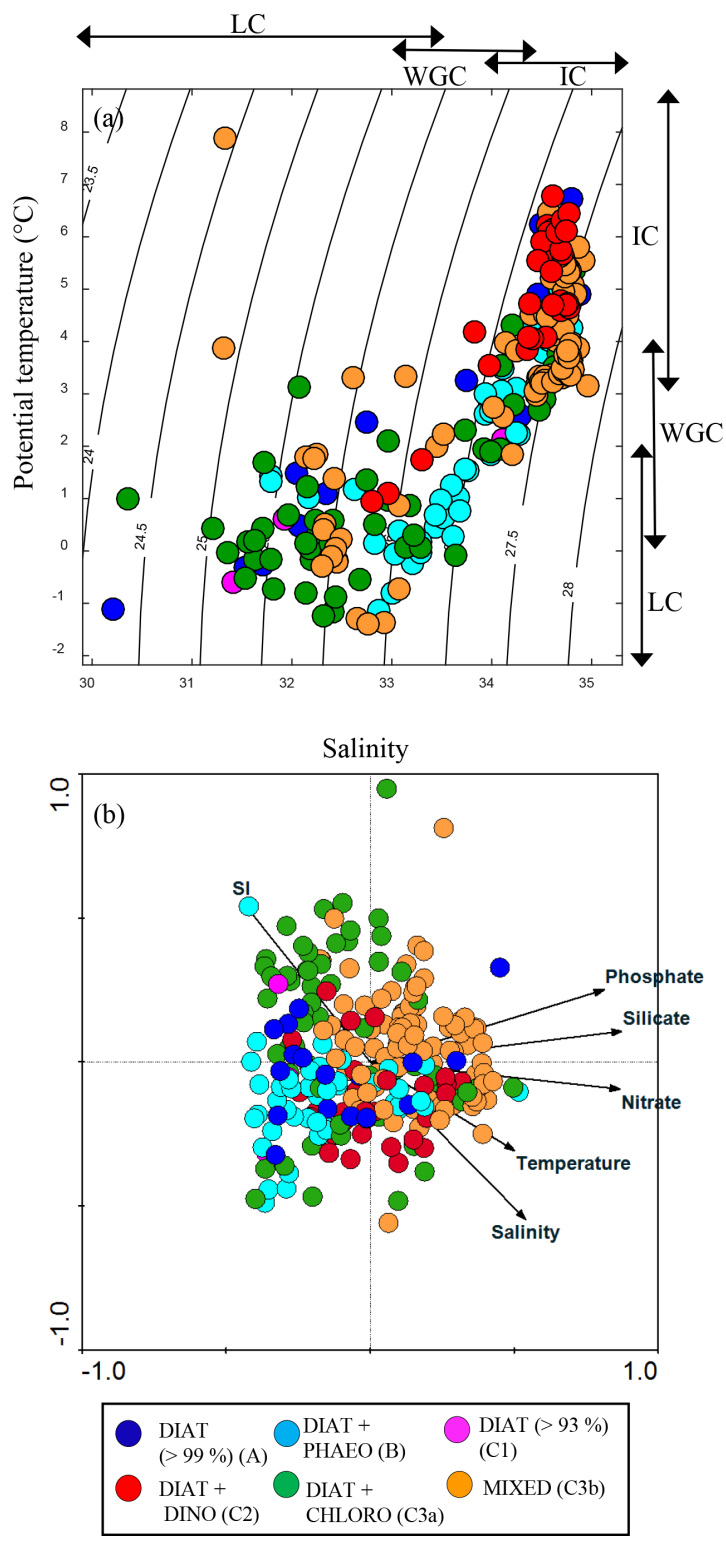

Figure 5. Positions of individual stations in relation to temperature $\left({ }^{\circ} \mathrm{C}\right)$ and salinity (a) and redundancy analysis (RDA) ordination plot (b). The stations are colour-coded according to the cluster groups (see details in Fig. 4). The TS plot (a) shows the approximate ranges of potential temperature $\left({ }^{\circ} \mathrm{C}\right)$ and salinity of the Labrador Current (LC), the West Greenland Current (WGC) and the Irminger Current (IC). Arrows in (b) show the explanatory (environmental) variables used in the analysis.

Stratification index (SI) was the only explanatory variable that had no statistical significance in explaining the distribution of phytoplankton communities (Table 4b).

The first axis ( $x$ axis) of the analysis, which explained most of the variance, clearly shows that the phytoplankton communities are associated with environmental parameters (Fig. 5b). Thus, stations in Arctic waters were to the left of the $y$ axis (low nutrients, temperatures, and salinity val- ues), while stations located in Atlantic waters were to the right (opposite trend, Fig. 5b). A community dominated by diatoms and chlorophytes (cluster $\mathrm{C} 3 \mathrm{a}$, upper left quadrant of Fig. 5b) was associated with lower salinities and temperatures, and highly stratified waters. Another community dominated by Phaeocystis and diatoms (cluster B, lower left quadrant of Fig. 5b) was associated with waters where nutrient concentrations (mainly nitrate, but also phosphate and silicate) were relatively low (average nitrate concentration for cluster $\mathrm{B}<3 \mu \mathrm{mol} \mathrm{L}{ }^{-1}$, Table 5). In Atlantic waters (upper and lower right quadrants (Fig. 5b)), the phytoplankton community was composed of mixed taxa during May (orange circles), but became dominated by diatoms and dinoflagellates during the bloom in June (red circles), showing a clear temporal succession in these waters. Thus, mixed assemblages (cluster C3b) were associated with higher nutrient concentrations (pre-bloom conditions in Atlantic waters, upper right quadrant), whereas dinoflagellates and diatoms (cluster C2) were associated with warmer and saltier waters, resembling bloom conditions in Atlantic waters induced by thermal stratification (lower right quadrant of Fig. 5b).

\subsection{Phytoplankton distribution and elemental stoichiometry}

Particulate organic carbon (POC) collected on filters can include organic carbon from a variety of sources, such as phytoplankton, bacteria, zooplankton, viruses, and detritus (Sathyendranath et al., 2009). Assuming that phytoplanktonassociated organic carbon, as estimated from phytoplankton cell volumes $\left(\mathrm{POC}_{\text {phyto }}\right)$ is strongly correlated with chlorophyll $a$ values, the proportion of $\mathrm{POC}_{\text {phyto }}$ should increase in eutrophic waters, which usually occurs with high chlorophyll $a$ and POC concentrations, and that it should be lower in oligotrophic waters. Indeed, our results showed higher proportions of $\mathrm{POC}_{\text {phyto }}(>60 \%)$ in waters with higher POC concentrations (Fig. 6a). However, there were several stations where POC levels were high and where the contribution of $\mathrm{POC}_{\text {phyto }}$ was low, suggesting that there may have been other sources of POC (e.g. detritus).

To investigate the influence of phytoplankton community structure on the stoichiometry of particulate organic material of surface Labrador Sea waters, the relationships between $\mathrm{POC}_{\text {phyto }}$ (the estimated proportion of POC from phytoplankton) and the ratio of POC to PON were examined. In general, different phytoplankton communities had distinct relationships between POC $_{\text {phyto }}$ and POC: PON. Stations in shelf regions, which have higher inputs of Arctic and glacial melt waters (lower salinity values), where diatoms co-dominated with chlorophytes in the west and east (cluster C3a) or with Phaeocystis in the east (cluster B), had higher and more variable values for POC: PON ratios than did stations influenced by Atlantic water (Fig. 6b). Some shelf stations had relatively high proportions of $\mathrm{POC}_{\text {phyto }}$ to total POC, suggesting that phytoplankton community growth 
Table 4. Results of the redundancy analyses (RDA) with the eigen-values, taxa-environmental correlations and percentages of variance explained used in the analysis (a). Automatic forward selection (a posteriori analysis) was used to determine the environmental variable(s) that best explain the variance of the data (b). The subset of environmental variable(s) that significantly explained phytoplankton distribution are referred to as marginal effects $\left(\lambda_{1}\right)$ when analysed individually, or conditional effects $\left(\lambda_{\mathrm{a}}\right)$ when analysed additively in the model (b). Explanatory variables are temperature $\left({ }^{\circ} \mathrm{C}\right)$, salinity, nitrate $\left(\mathrm{NO}_{3}^{-} ; \mu \mathrm{mol} \mathrm{L}{ }^{-1}\right)$, phosphate $\left(\mathrm{PO}_{4}^{3-} ; \mu \mathrm{mol} \mathrm{L}-1\right)$, silicate $(\mathrm{Si}(\mathrm{OH}) 4 ; \mu \mathrm{mol} \mathrm{L}-1)$, and stratification index $(\mathrm{SI})\left(\mathrm{kg} \mathrm{m}^{-4}\right)$. Significant $p$ values $(p<0.05)$ represents the variables that explain the variation in the analyses.

\begin{tabular}{|c|c|c|c|c|c|c|}
\hline (a) Axes & 1 & 2 & 3 & 4 & & Total variance \\
\hline Eigen-values & 0.26 & 0.04 & 0.005 & 0 & & 1 \\
\hline Taxa-environment correlations & 0.68 & 0.4 & 0.321 & 0.25 & & \\
\hline Cumulative percentage variance & & & & & & \\
\hline of species data & 25.7 & 29.9 & 30.3 & 30.7 & & \\
\hline of species-environment relation & 83.5 & 97.2 & 98.8 & 99.8 & & \\
\hline Sum of all eigenvalues & & & & & & 1 \\
\hline Sum of all canonical eigenvalues & & & & & & 0.31 \\
\hline (b) Marginal effects & \multicolumn{5}{|c|}{ Conditional effects } & \\
\hline Variable & $\lambda_{1}$ & & Variable & $\lambda_{\mathrm{a}}$ & $p$ & $F$ \\
\hline $\mathrm{Si}(\mathrm{OH})_{4}$ & 0.2 & & $\mathrm{Si}(\mathrm{OH})_{4}$ & 0.2 & 0.001 & 61.7 \\
\hline $\mathrm{NO}_{3}^{-}$ & 0.19 & & Temperature & 0.05 & 0.001 & 17.3 \\
\hline $\mathrm{PO}_{4}^{3-}$ & 0.17 & & Salinity & 0.02 & 0.002 & 6.94 \\
\hline Salinity & 0.09 & & $\mathrm{NO}_{3}^{-}$ & 0.01 & 0.016 & 4.31 \\
\hline Temperature & 0.07 & & $\mathrm{PO}_{4}^{3-}$ & 0.02 & 0.002 & 7.22 \\
\hline SI & 0.06 & & SI & 0.01 & 0.153 & 1.72 \\
\hline
\end{tabular}

dominated by diatoms and chlorophytes (cluster C3a) contributed to a high proportion of the total POC (most stations from cluster $\mathrm{C} 3 \mathrm{a}$ had $\mathrm{POC}_{\text {phyto }}>50 \%$ ) (Fig. 6b). On the other hand, some shelf stations, particularly the one dominated by a community composed of diatoms and Phaeocystis (cluster B), had high POC: PON ratios (>10), with low $\mathrm{POC}_{\text {phyto }}$ contributions, suggesting an increased contribution of detritus to the total POC (Fig. 6c). Stations influenced by Atlantic waters had generally lower contributions of $\mathrm{POC}_{\text {phyto }}$ compared to Arctic-related waters, with most stations having POC: PON ratios < 6.6 (Fig. 6c).

\subsection{Physiological patterns}

The linear relationship of accessory pigment (AP) versus total chlorophyll $a$ (TChl $a$ ) was investigated, given that it is often used as an index of quality control in pigment analysis (Aiken et al., 2009). This relationship could also represent a response of phytoplankton communities to light conditions, given that AP allows a broader range of wavelengths to be absorbed (chromatic adaptation), whereas TChl $a$ concentrations would vary according to light intensities (lightshade adaptation) (Boyton et al., 1983). The log-log linear relationship of AP versus total chlorophyll $a$ (TChl $a$ ) from surface waters of the Labrador Sea varied with temperature (Fig. 7a) and among the distinct phytoplankton communities (Fig. 7b). Phytoplankton communities in cold waters (of Arctic origin), such as those co-dominated by diatoms and
Phaeocystis in the east and diatoms and chlorophytes in the west, had a lower ratio of accessory pigments to TChl $a$ $(\log \mathrm{AP}: \log \mathrm{TChl} a$ ) (slope of 0.86 and 0.89 , respectively) than communities from warmer waters (Irminger Current from Atlantic origin), particularly those co-dominated by diatoms and dinoflagellates $(\log \mathrm{AP}: \log \mathrm{TChl} a$, slope of 1.03) (Fig. 7b). Slopes of the $\log$ AP to $\log$ TChl $a$ relationships were not statistically different among the different communities (ANCOVA, $p>0.05$ ), except for those communities co-dominated by diatoms and Phaeocystis (cluster B), which had a slope that was statistically different from the others (ANCOVA, $p=0.016$ ).

Photosynthetic parameters differed among the different phytoplankton communities. Photosynthetic efficiencies $\left(\alpha^{\mathrm{B}}\right)$ were the lowest in communities dominated by Phaeocystis and diatom communities in the east of the transect (near Greenland, cluster B) (average $\alpha^{\mathrm{B}}=6.8 \times 10^{-2} \mathrm{mg} \mathrm{C}$ $\left.\left[\mathrm{mgChl} a_{\mathrm{f}}\right] \mathrm{h}^{-1}\left[\mathrm{~W} \mathrm{~m}^{-2}\right]^{-1}\right)$ and the highest in communities dominated by diatoms and chlorophytes (cluster C3a) typically found in the west (Labrador Current) $\left(\alpha^{\mathrm{B}}=9.2 \times 10^{-2} \mathrm{mgC}\left[\mathrm{mg} \mathrm{Chl} a_{\mathrm{f}}\right] \mathrm{h}^{-1}\left[\mathrm{~W} \mathrm{~m}^{-2}\right]^{-1}\right) \quad(\mathrm{Ta}-$ ble 5). The light intensity approximating the onset of saturation $\left(E_{k}\right)$ had the opposite pattern: it was highest in communities dominated by Phaeocystis and diatoms (average $E_{k}=60 \pm 33 \mathrm{~W} \mathrm{~m}^{-2}$ ) and lowest at stations dominated by diatoms and chlorophytes $\left(E_{k}=29 \mathrm{~W} \mathrm{~m}^{-2}\right)$ (Table 5). Phaeocystis and diatom communities also showed little photoinhibition $\left(\beta=4 \times 10^{-4} \mathrm{mgC}\left[\mathrm{mgChl} a_{\mathrm{f}}\right] \mathrm{h}^{-1}\right.$ 

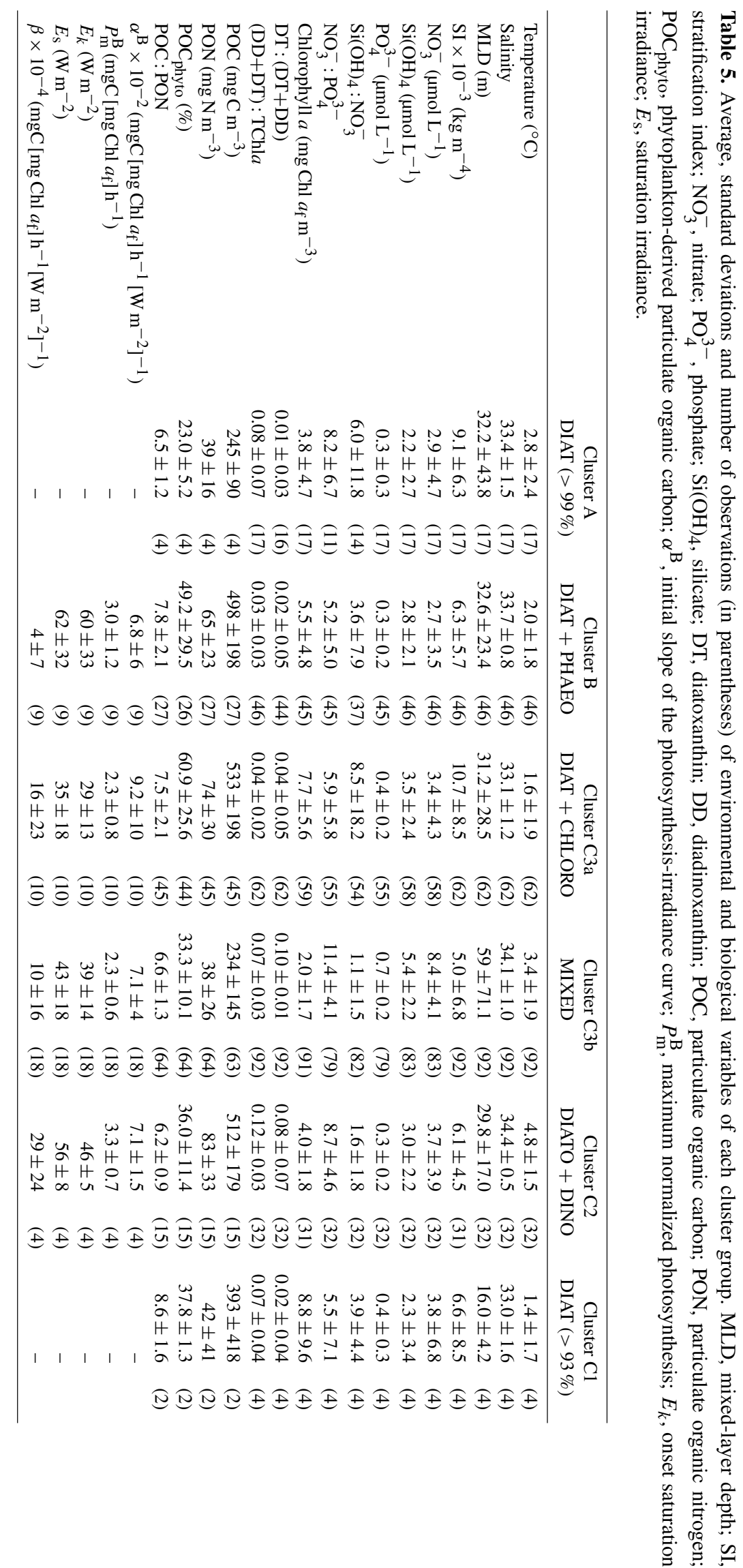

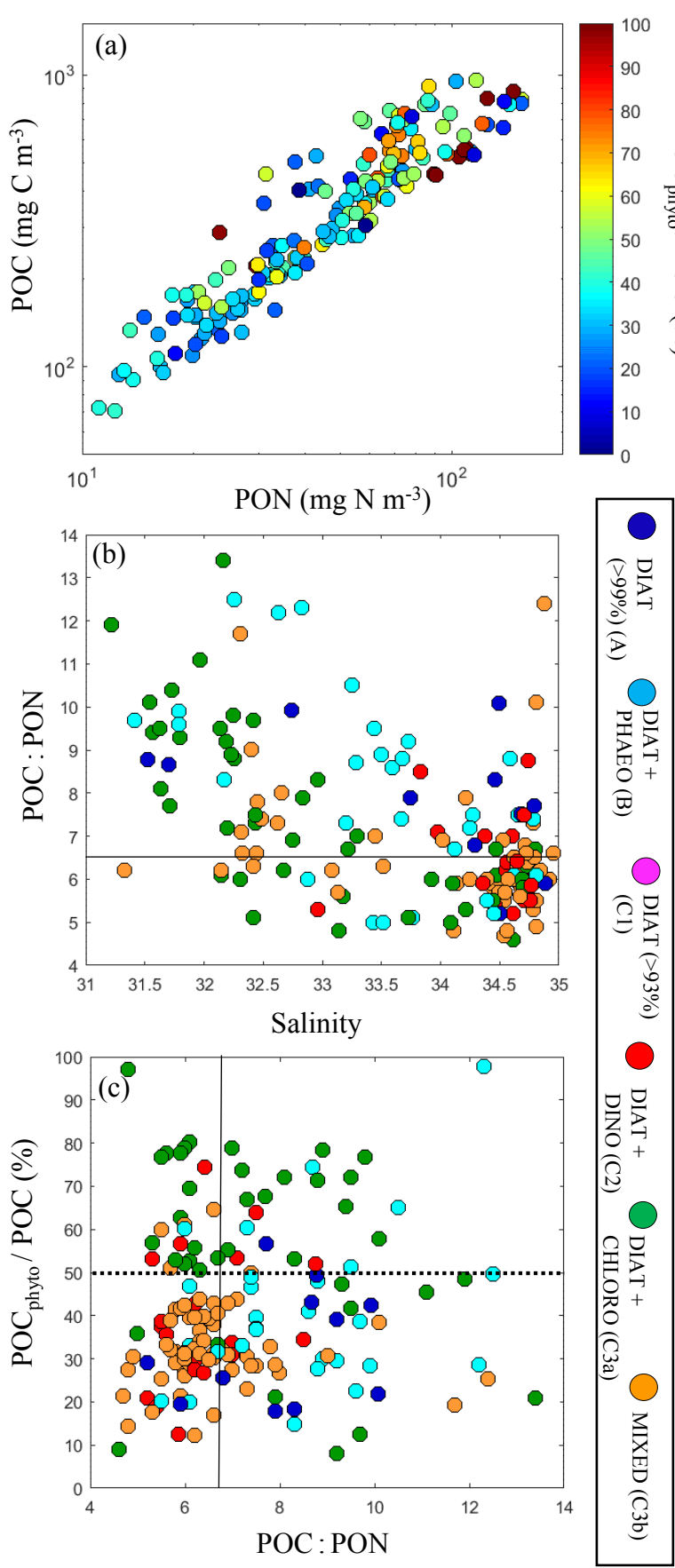

Figure 6. Relationship between particulate organic carbon (POC) and particulate organic nitrogen (PON) in a logarithmic scale, with the points (stations) as a function of phytoplankton-derived organic carbon content $\left(\mathrm{POC}_{\text {phyto }} / \mathrm{POC}, \%\right)$ (a), POC: $\mathrm{PON}$ versus salinity (b), phytoplankton-derived organic carbon content $\left(\mathrm{POC}_{\text {phyto }} / \mathrm{POC}, \%\right)$ versus the POC : PON ratio (c). The points (stations) in (b) and (c) are colour-coded according to the cluster groups (see details in Fig. 4). Solid lines in (b) and (c) show the $\mathrm{C}: \mathrm{N}$ Redfield ratio of 6.6 and the dashed line in (c) shows where $\mathrm{POC}_{\text {phyto }}$ contributes $50 \%$ of the total POC.

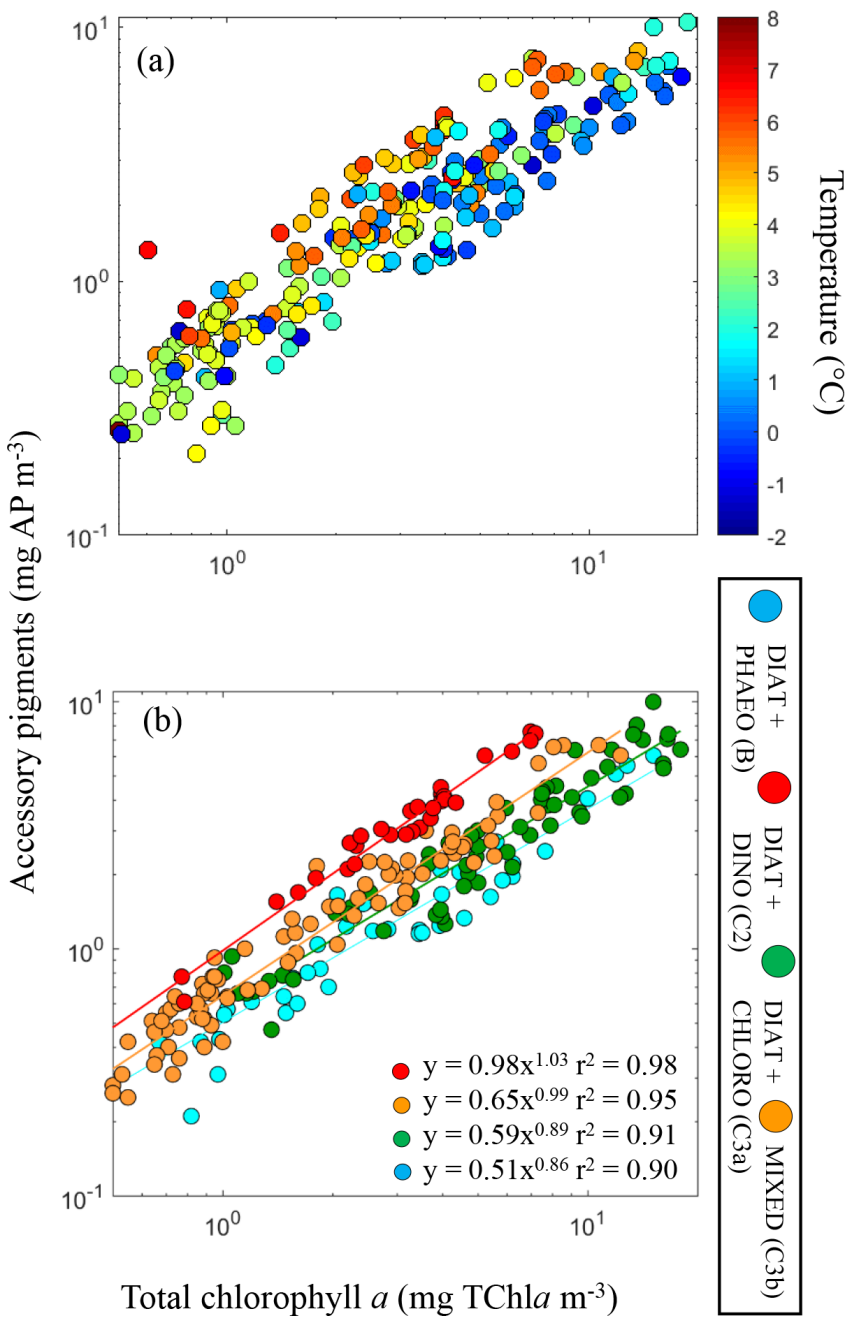

Figure 7. Relationship between total accessory pigments $\left(\mathrm{mg} \mathrm{AP} \mathrm{m}^{-3}\right)$ and total chlorophyll $\left(\mathrm{mg} \mathrm{TChl} a \mathrm{~m}^{-3}\right)$ on a logarithmic scale, with the points (stations) according to temperature (a) and colour-coded according to phytoplankton community cluster group (see details in Fig. 4) (b).

$\left[\mathrm{W} \mathrm{m}^{-2}\right]^{-1}$ ). Phytoplankton communities in Atlantic waters (clusters $\mathrm{C} 3 \mathrm{~b}$ and $\mathrm{C} 2$ ) had the highest levels of photoprotective pigments, such as those used in the xanthophyll cycle (diadinoxanthin (DD) + diatoxanthin (DT)) : TChl $a$ $>0.07$ ), particularly those communities co-dominated by diatoms and dinoflagellates (cluster $\mathrm{C} 2$ ) from stratified Atlantic waters (Table 5). These communities were the most susceptible to photoinhibition $\left(\beta=29 \times 10^{-4} \mathrm{mgC}\right.$ $\left.\left[\mathrm{mg} \mathrm{Chl} a_{\mathrm{f}}\right] \mathrm{h}^{-1}\left[\mathrm{~W} \mathrm{~m}^{-2}\right]^{-1}\right)$, had the highest ratios of photoprotective pigments to TChl $a$ ((DD+DT): TChl $a=$ $0.12 \pm 0.01)$, and the highest maximum photosynthetic rates $\left(P_{\mathrm{m}}^{\mathrm{B}}=3.3 \pm 0.7 \mathrm{mg} \mathrm{C}\left[\mathrm{mg} \mathrm{Chl} a_{\mathrm{f}}\right] \mathrm{h}^{-1}\right)$ (Table 5). 


\section{Discussion}

\subsection{Biogeography of phytoplankton communities in the Labrador Sea}

In this study, our assessment of phytoplankton pigments from surface waters of the Labrador Sea during spring/early summer are based on a decade of observations and show that the distribution of phytoplankton communities varied primarily within distinct waters masses in surface waters (Labrador, Irminger and Greenland Currents). However, a temporal succession of phytoplankton communities from the central region of the Labrador Sea was also observed as waters became thermally stratified from May to June. Major blooms (Chl $a_{\mathrm{f}}$ concentrations $>3 \mathrm{mg} \mathrm{Chl} a_{\mathrm{f}} \mathrm{m}^{-3}$ ) occurred on or near the shelves in shallower mixed layers $(<33 \mathrm{~m}$, Table 5$)$. Diatoms were abundant in these blooms; however, they often co-dominated with (1) chlorophytes in the west (mostly in the Labrador Current) and (2) Phaeocystis in the east in the West Greenland Current. A more diverse community with low chlorophyll $a$ values (average $\mathrm{Chl} a_{\mathrm{f}}$ concentrations $\sim 2 \mathrm{mg} \mathrm{Chl} a_{\mathrm{f}} \mathrm{m}^{-3}$, Table 5) was found earlier in the season (May) in deeper mixed layers (>59 m, Table 5) in the central basin. Once these waters of the central basin became thermally stratified (June), a third bloom co-dominated by diatoms and dinoflagellates occurred, revealing an ecological succession from mixed flagellate communities. These patterns are similar to those seen in other shelf and basin regions of Arctic/subarctic waters (e.g. Coupel et al., 2015; Fujiwara et al., 2014; Hill et al., 2005).

It is well known that diatoms tend to dominate in highnutrient regions of the ocean due to their high growth rates, while their low surface area to volume ratios mean that they do not do as well as smaller nano- or picoplankton in lownutrient conditions (Gregg et al., 2003; Sarthou et al., 2005). The Labrador Sea is a high-nutrient region during early spring due to deep winter mixing (200-2300 m) that provides nutrients to the surface layers. Thus, high nutrient concentrations may have supported the blooms dominated by diatoms once light became available, as observed in previous studies (Fragoso et al., 2016; Harrison et al., 2013; Yashayaev and Loder, 2009).

Chlorophytes were the second most abundant phytoplankton group in this study, particularly in the central-western part of the Labrador Sea, but occasionally occurring in the east as well. Chlorophytes are thought to contribute 1-13\% of total chlorophyll $a$ in the global ocean (Swan et al., 2015) and to inhabit transitional regions, where nutrient concentrations become limiting for diatoms but are not persistently low enough to prevent growth due to nutrient limitation, as occurs in the oligotrophic gyres (Gregg et al., 2003; Gregg and Casey, 2007; Ondrusek et al., 1991). The Labrador Shelf is a dynamic region during springtime, where melting sea ice in May provides a local freshwater input (Head et al., 2003). Melting sea ice provides intense stratification and shallow mixed layers for the phytoplankton, with increased access to light, which promotes rapid growth of cold Arctic/icerelated phytoplankton near the sea ice shelf (Fragoso et al., 2016). It is possible that the rapid nutrient exhaustion in highly stratified ice-melt waters might have stimulated the growth of chlorophytes as a succession from large diatoms to smaller phytoplankton forms. Chlorophytes, as well as prasinophytes, such as Pyramimonas, a genus found in high abundances in surface Labrador Shelf waters, has been previously associated with land-fast (Palmer et al., 2011) and melting sea ice, given that they have been found blooming (chlorophyll $a$ concentration $\sim 30 \mathrm{mg} \mathrm{Chl} a_{\mathrm{f}} \mathrm{m}^{-3}$ ) in lowsalinity melt waters (salinity, 9.1) under the Arctic pack ice (Gradinger, 1996).

Dinoflagellates, in this study, were associated with the Irminger Current, where they were occasionally found blooming with diatoms in the warmer, stratified Atlantic waters of the central basin. These blooms dominated by dinoflagellates and Atlantic diatom species, such as Ephemera planamembranacea and Fragilariopsis atlantica, start later in the season (end of May or June) as thermal stratification develops in the central Labrador Sea (Frajka-Williams and Rhines, 2010; Fragoso et al., 2016). Transition from diatoms to dinoflagellates has been well documented in the North Atlantic between spring and summer, and occurs mainly as dinoflagellates can use mixotrophic strategies to alleviate nutrient limitation as waters become warmer, highly stratified and nutrient depleted (Barton et al., 2013; Head et al., 2000; Head and Pepin, 2010; Henson et al., 2012; Leterme et al., 2005). The North Atlantic Oscillation index (NAO) and sea surface temperatures (Zhai et al., 2013) appear to influence the relative proportions of diatoms and dinoflagellates as well as the variability in the start date of the North Atlantic bloom. A negative winter phase of NAO is associated with weaker northwest winds over the Labrador Sea and reductions in the depth of winter mixing and supply of nutrients to the upper layers (Drinkwater and Belgrano, 2003). Vertical stability, thermal stratification, and the initiation of the spring bloom tend to occur earlier under negative NAO conditions and the proportion of dinoflagellates in the warmer, more nutrientlimited waters may be higher (Zhai et al., 2013). Unfortunately, it was not possible to investigate the influence of NAO on the relative contribution of dinoflagellates and diatoms in the Labrador Sea section of the North Atlantic in this study, given that the sampling period varied from early/mid-May to mid-/late June. However, abundances of dinoflagellates appeared to be higher in warmer waters $\left(>5^{\circ} \mathrm{C}\right)$, suggesting that the communities were shifting from diatoms to dinoflagellates as the water became stratified and nutrient concentrations decreased.

In this study, a community dominated by Phaeocystis and diatoms was observed blooming together in waters of the WGC, in the eastern central part of the Labrador Sea. The occurrence of Phaeocystis in these waters has been observed before by several authors (Fragoso et al., 2016; Frajka- 
Williams and Rhines, 2010; Harrison et al., 2013; Head et al., 2000; Stuart et al., 2000; Wolfe et al., 2000). The eastern part of the Labrador Sea is a region with high eddy kinetic energy during spring (Chanut et al., 2008; Frajka-Williams et al., 2009; Lacour et al., 2015), which causes the accumulation of low-salinity surface waters from the West Greenland Current. This buoyant freshwater layer contains elevated levels of algal biomass of both Phaeocystis and diatoms (this study, Fragoso et al., 2016). Mesoscale eddies may stimulate growth of Phaeocystis and diatoms by inducing partial stratification at irradiance levels that are optimal for their growth, but too low for their competitors (blooms in these eddies usually start in April). Lacour et al. (2015) showed that irradiance levels estimated from satellite-derived PAR and mixed-layer depth climatologies are similar for thermally and haline-stratified spring blooms in the Labrador Sea. Nonetheless, these authors recognize the need for in situ measurements to confirm whether Labrador Sea spring blooms, presumably composed of distinctive phytoplankton communities, respond in the same manner to light-mixing regimes. The ability of Phaeocystis to grow under dynamic light irradiances explains why they are often found in deeper mixed layers, such as those found in Antarctic polynyas (Arrigo, 1999; Goffart et al., 2000), although this genus can also occur in shallow mixed layers, such as those found close to ice edges (Fragoso and Smith, 2012; Le Moigne et al., 2015).

Mesoscale eddies are also often associated with elevated zooplankton abundances (Frajka-Williams et al., 2009; Yebra et al., 2009). In the Labrador Sea, lower grazing rates have been observed in blooms dominated/co-dominated by colonial Phaeocystis, which are often located in these eddies and which may, in turn, explain why this species is dominant (Head and Harris, 1996; Wolfe et al., 2000). Although the exact mechanism that facilitates Phaeocystis growth in the northeastern region of the Labrador Sea is not clear, it is evident that blooms of this species are tightly linked to mesoscale eddies, and that this relationship needs further investigation to better explain their regular reoccurrence in these waters.

\subsection{Phytoplankton composition and related biogeochemistry}

Particulate organic carbon (POC) and nitrogen (PON) concentrations, as well as the molar ratio of POC: PON varied within distinct hydrographic zones, indicating the presence of different biogeochemical provinces in the Labrador Sea. A canonical Redfield ratio of 6.6 for POC : PON appears to represent the global average (Redfield, 1958), although regional variations on the order of 15 to $20 \%$ have also been reported (Martiny et al., 2013b). The POC: PON appears to be closer to the Redfield ratio of 6.6 in productive subarctic/Arctic waters, such as the northern Baffin Bay (Mei et al., 2005), the northeastern Greenland Shelf (Daly et al., 1999), and in Fram Strait and the Barents Sea (Tamelander et al.,
2012). Crawford et al. (2015), however, recently reported very low POC: PON ratios in oligotrophic Arctic waters of the Beaufort Sea and Canada Basin, where depth-integrated values of the POC: $\mathrm{PON}$ ratio were $\sim 2.65$, much lower than those in more productive domains, such as the subarctic central Labrador Sea (POC: PON 4).

In this study, highly productive surface waters of Arctic origin (near or over the shelves) had higher phytoplanktonderived particulate organic carbon $\left(\mathrm{POC}_{\text {phyto }}>43 \%\right.$ of total POC, Fig. 6c), as well as higher and more variable POC $:$ PON ratios (average $>6.9$, Fig. 6b) compared with stations influenced by Atlantic water (average POC:PON $<6.3, \mathrm{POC}_{\text {phyto }}>35 \%$, Fig. 6b). Diatoms have been suggested to contribute to higher phytoplankton-derived POC in Arctic/subarctic waters (Crawford et al., 2015). The Labrador Shelf region, where blooms are generally dominated by large Arctic/ice-related diatoms (Fragoso et al., 2016), had relatively high contributions of $\mathrm{POC}_{\text {phyto }}$ $(>50 \%)$ to the total POC, even though smaller phytoplankton forms, such as chlorophytes, were also abundant. Low POC : $\mathrm{PON}$ ratios, as well as low $\mathrm{POC}_{\text {phyto }}$ concentrations, were associated with Atlantic waters, which had higher contributions of flagellates (particularly before bloom initiation). Similar findings were reported by Crawford et al. (2015), where low $\mathrm{POC}_{\text {phyto }}$ was associated with larger contributions of flagellates $(<8 \mu \mathrm{m})$ in oligotrophic Arctic waters, such as the Beaufort Sea and Canada Basin. Crawford et al. (2015) also considered that POC: $\mathrm{PON}$ ratios might have been reduced by the presence of heterotrophic microbes (bacteria, flagellates and ciliates) since these microorganisms have POC : PON ratios much lower than the canonical Redfield ratio of 6.6 (Lee and Fuhrman, 1987; Vrede et al., 2002). Bacteria and other heterotrophic organisms were not quantified in our study, although Li and Harrison (2001) have shown that bacterial biomass from surface waters was $62 \%$ greater (average from 1989 to 1998 of $13.8 \mathrm{mg} \mathrm{C} \mathrm{m}^{-3}$ ) in the central region than in shelf areas of the Labrador Sea.

Changes in POC: PON may also be related to the physiological status of phytoplankton and/or community structure. In the North Water Polynya (Baffin Bay), POC: PON ratios during phytoplankton blooms increased between spring (5.8) and summer (8.9) as phytoplankton responded to nitrate starvation by producing $\mathrm{N}$-poor photoprotective pigments (Mei et al., 2005). Daly et al. (1999) also found high POC: PON ratios $(\sim 8.9)$ in Arctic surface waters dominated by diatoms on the northeastern Greenland Shelf, which were attributed to nutrient limitation. Atlantic waters appear to have an excess of nitrate compared with Arctic waters (Harrison et al., 2013), which could explain why phytoplankton from Atlantic Waters had lower POC: PON ratios in our study (Fig. 6c). Conversely, Arctic-influenced waters on or near the shelves had higher $\mathrm{Si}(\mathrm{OH})_{4}: \mathrm{NO}_{3}^{-}$and lower $\mathrm{NO}_{3}^{-}: \mathrm{PO}_{4}^{3-}$ than those in the central basin in this study (Fig. $2 \mathrm{k}$ and 1 ), which could also have contributed to the observed high POC : PON ratios. 
A few stations in shelf waters of the Labrador Sea also had remarkably high $\mathrm{POC}: \mathrm{PON}$ ratios $(>10)$, and low $\mathrm{POC}_{\text {phyto }}$ contributions, suggesting high contributions of detritus. These waters probably receive higher inputs of Arctic and glacial ice melt, which could introduce POC from external sources. Hood et al. (2015) showed that POC export from glaciers is large, particularly from the Greenland Ice Sheet and it occurs in suspended sediments derived from glacier meltwater. High POC: PON ratios ( $>10)$, particularly in waters where Phaeocystis were abundant, may also be linked to the mucilaginous matrix of the Phaeocystis colonies (Palmisano et al., 1986). The mucopolysaccharide appears to contain excess carbon, particularly when nutrients start to become depleted and colonies become senescent (Alderkamp et al., 2007; Wassmann et al., 1990).

\subsection{Physiological parameters of distinct phytoplankton communities}

Accessory pigments (AP) are assumed to have a ubiquitous, global, log-log linear relationship with chlorophyll $a$ in aquatic environments (Trees et al., 2000). This linear relationship is often used as an index of quality control in pigment analysis, which is required due to uncertainties of the quantitative comparability of data among different surveys, and may be related to differences in analytical procedures and sample storage methods used in different laboratories. In the current study, the slope of AP to total chlorophyll $a$ (TChl $a$ ) on a logarithm scale (Fig. 7) passed the quality control criteria of slopes ranging from 0.7 to 1.4 and $r^{2}>0.90$ as applied in previous studies (e.g. Aiken et al., 2009; Peloquin et al., 2013; Thompson et al., 2011) and were within the range observed throughout worldwide aquatic systems (slope from 0.8 to 1.3 compared to 0.86 to $1.03 \mathrm{ob}-$ served in our study) (Trees et al., 2000). An interesting trend was also found where phytoplankton pigment ratios varied clearly within distinct communities in the Labrador Sea. According to our data, phytoplankton communities found in colder waters (of Arctic origin) had lower accessory pigments ratios to total chlorophyll $a$ ratio $(\log \mathrm{AP}: \log \mathrm{TChl} a)$ (slope, 0.86) when compared to communities from warmer waters (Irminger Current from Atlantic origin) (slope, 1.03). Changes in the ratios of $\log \mathrm{AP}: \log \mathrm{TCh} l a$ as a function of phytoplankton community composition has also been previously observed by Stramska et al. (2006). These authors showed a higher slope of $\log \mathrm{AP}: \log \mathrm{TCh} l a$ when dinoflagellates were dominant during summer in northern polar Atlantic waters as opposed to lower ratios associated with flagellates in spring. Trees et al. (2000) and Aiken et al. (2009) also reported lower $\log \mathrm{AP}: \log \mathrm{TChl} a$ (slope $<1.00)$ in oligotrophic waters dominated by picoplankton as opposed to higher ratios in upwelling waters where microplankton, particularly diatoms, were dominant.

Environmental parameters, such as nutrients and light conditions, have also been suggested to influence lo-
gAP : $\log$ TChl $a$, regardless of community composition (Trees et al., 2000). However, in our study, these parameters, analysed as nitrate and silicate concentrations and stratification index, did not vary with $\log \mathrm{AP}: \log \mathrm{TChl} a$ (data not shown) as opposed to temperature. Phytoplankton community distributions varied clearly according to temperature with Phaeocystis occurring in colder Arctic waters and dinoflagellates in warmer Atlantic waters. Although both communities were co-dominated by diatoms (relative abundance $>70 \%$ of total chlorophyll $a$ ), the ratio $\log$ AP : $\log$ TChl $a$ varied considerably, suggesting that diatom species from both Arctic and Atlantic waters varied intrinsically in pigment composition, as observed by the distinct Fuco to TChl $a$ ratios of shelf (Arctic) versus central (Atlantic) waters (Table S1, Supplement). Fragoso et al. (2016) have previously observed that the diatom species from Arctic and Atlantic waters of the Labrador Sea during spring varied in terms of species composition. According to the study by Fragoso et al. (2016), the diatoms Ephemera planamembranacea and Fragilariopsis atlantica were typically found in Atlantic waters, whereas polar diatoms, including Thalassiosira species (T. hyalina, T. nordenskioeldii, for example), in addition to Bacterosira bathyomphala, Fossula arctica, Nitzschia frigida, and Fragilariopsis cylindrus, were all found in Arctic-influenced waters. It is possible that the distinct composition of diatoms from these biogeographical regions might have influenced the pigment composition in these waters. Likewise, it is possible that temperature had a strong physiological effect on the $\log$ AP : $\log$ TChl $a$ ratio. Many environmental factors, such as turbulence and coloured dissolved organic matter (CDOM) concentrations, could have contributed to the variance of chlorophylls (lightshade adaptation) and AP (chromatic adaptation) observed due to changes they cause in spectral light absorption by phytoplankton. Turbulence and CDOM, however, were not measured in this study and a direct physiological temperatureinduced effect or taxonomic effect on $\log \mathrm{AP}: \log \mathrm{TChl} a$ is currently unknown.

The variation in photosynthetic parameters in the distinct phytoplankton biogeographical provinces demonstrated how each phytoplankton community responds to environmental conditions. Harrison and Platt (1986) found that the photophysiology of phytoplankton from the Labrador Sea is influenced by temperature and irradiance. Nonetheless, phytoplankton composition may also influence the values of the photosynthetic parameters. Light-saturated photosynthetic rates and saturation irradiances, for instance, were higher at stations where diatoms were dominant $(>70 \%)$, as opposed to stations where flagellates were more abundant (from 40 up to $70 \%$ ). Similar findings were reported by Huot et al. (2013), who observed that light-saturated photosynthetic rates in the Beaufort Sea (Arctic Ocean) were higher for communities composed of large cells, presumably diatoms, compared to smaller flagellates. 
Polar phytoplankton communities from shelf waters (east versus west) observed in this study had distinctive photophysiological characteristics. Comparing these blooms, diatom/chlorophyte communities (west) had higher photosynthetic efficiency $\left(\alpha^{\mathrm{B}}=9.2 \times 10^{-2} \mathrm{mgC}\right.$ [mg Chl $\left.\left.a_{\mathrm{f}}\right] \mathrm{h}^{-1}\left[\mathrm{~W} \mathrm{~m}^{-2}\right]^{-1}\right)$, lower onset light-saturation irradiance $\left(E_{k}=29 \mathrm{~W} \mathrm{~m}^{-2}\right)$, and higher photoinhibition $\left(\beta=16 \times 10^{-4} \mathrm{mgC}\left[\mathrm{mgChl} a_{\mathrm{f}}\right] \mathrm{h}^{-1}\left[\mathrm{~W} \mathrm{~m}^{-2}\right]^{-1}\right)$ than communities from the east. This suggests that the community located in the Labrador Shelf waters (west) was more light-stressed compared to the community observed in the east (diatom/Phaeocystis). Haline-stratification due to the influence of Arctic waters occurs in both regions during spring, contributing to the shallow mixed-layer depths $(<33 \mathrm{~m})$ observed (Table 5). However, waters from the Labrador Shelf (west, Cluster C3a) were more stratified than the Greenland Shelf (cluster B, see SI values, Table 5) because of the local sea ice melt observed in this area, which contributes to increased stratification in this region. The diatom species observed on the Labrador Shelf were mostly sea ice related (Fragilariopsis cylindrus, Fossula arctica, Nitzschia frigida) compared to pelagic species observed in the Greenland Shelf waters (Thalassiosira gravida, for example) (Fragoso et al., 2016). Sensitivity of sea-icerelated diatoms to irradiances $>15 \mu \mathrm{mol}$ photons $\mathrm{m}^{-2} \mathrm{~s}^{-1}$ has been reported (Alou-Font et al., 2016), which could help explain why phytoplankton communities from the west were photoinhibited.

The communities dominated by Phaeocystis/diatoms located near Greenland (east) had the inverse pattern: low photosynthetic efficiency (average $\alpha^{\mathrm{B}}=6.8 \times 10^{-2} \mathrm{mgC}$ $\left.\left[\mathrm{mgChl} a_{\mathrm{f}}\right] \mathrm{h}^{-1}\left[\mathrm{~W} \mathrm{~m}^{-2}\right]^{-1}\right)$ and high onset lightsaturation irradiances $\left(E_{k}=60 \mathrm{~W} \mathrm{~m}^{-2}\right)$. This pattern in diatom/Phaeocystis-dominated communities mean that photosynthetic rates were relatively low at high light intensities, although photoinhibition was low $\left(\beta=4 \times 10^{-4} \mathrm{mg} \mathrm{C}\right.$ $\left.\left[\mathrm{mgChl} a_{\mathrm{f}}\right] \mathrm{h}^{-1} \quad\left[\mathrm{~W} \mathrm{~m}^{-2}\right]^{-1}\right)$. Phaeocystis antarctica, widespread in Antarctic waters, relies heavily on photodamage recovery, such as D1 protein repair (Kropuenske et al., 2009), which could explain how these communities overcome photoinhibition. Stuart et al. (2000), however, found a high photosynthetic efficiency $\left(\alpha^{\mathrm{B}}\right)$ for a population dominated by Phaeocystis near Greenland and attributed this to the small cell size of Phaeocystis. In addition to the exposure of ice-related diatoms to high light levels due to increased stratification, the high concentration of chlorophytes and prasinophytes, which are also small in cell size, might also explain the higher $\alpha^{\mathrm{B}}$ observed in the Labrador Shelf waters (west, cluster $\mathrm{C} 3 \mathrm{a}$ ), when compared to values from a community dominated by diatom/Phaeocystis blooms (east, cluster B).

Phytoplankton communities from Atlantic waters (co-dominated by diatoms and dinoflagellates) were highly susceptible to photoinhibition $\left(\beta=29 \times 10^{-4} \mathrm{mgC}\right.$ $\left.\left[\mathrm{mgChl} a_{\mathrm{f}}\right] \mathrm{h}^{-1}\left[\mathrm{~W} \mathrm{~m}^{-2}\right]^{-1}\right)$ compared with the other communities in the Labrador Sea. Days are longer and solar incidence is higher in June compared to May at these latitudes (Harrison et al., 2013). Dinoflagellates were found to bloom in the central Labrador Sea in June as a consequence of increased thermal stratification. To cope with high light levels and potential photodamage, this phytoplankton community appeared to increase the levels of photoprotective pigments, such as those used in the xanthophyll cycle (diadinoxanthin (DD) + diatoxanthin (DT)). These communities also had high diatoxanthin levels compared with the other phytoplankton communities in this study, suggesting that the community was experiencing higher light intensities (Moisan et al., 1998). Increases in photoprotective pigments, including (DD+DT)/TChl $a$, have also been reported to occur in Arctic phytoplankton communities from spring to summer, presumably as a response to higher irradiance (Alou-Font et al., 2016). Thus, photoprotective capacity can be a key determinant for phytoplankton survival and may also be related to the taxonomic segregation observed in Arctic and Atlantic phytoplankton communities.

\subsection{Phytoplankton communities assessed by HPLC and CHEMTAX methods}

A number of studies have used CHEMTAX methods to determine phytoplankton community structure in Arctic/subarctic waters (e.g. Coupel et al., 2012, 2015; Lovejoy et al., 2007; Piquet et al., 2014; Vidussi et al., 2004; Zhang et al., 2015). Spring phytoplankton communities from the Labrador Sea have already been investigated in detail (Fragoso et al., 2016), although the analysis did not include nanoand pico-flagellates (except cryptophytes and Phaeocystis pouchetii) and was done over only 4 years (2011-2014) at selected stations along the L3 (=AR7W) transect. Here, we have combined phytoplankton information from Fragoso et al. (2016) with additional pigment analyses. Although cross-comparison between these two techniques (carbon biomass estimated from microscopic counts versus algal group chlorophyll $a$ estimated from CHEMTAX) should not be expected to give exactly equivalent results, given that most flagellates observed in the pigment analysis were not counted under the microscope, some comparability should be possible, at least for the larger cells (e.g. diatoms).

Phaeocystis $\left(r^{2}=0.79\right)$ and diatom $\left(r^{2}=0.74\right)$ biomasses were well correlated when carbon biomasses estimated from microscopic counts when compared with CHEMTAXderived algal chlorophyll $a$ biomass (data not shown). Diatoms are the group that usually show the best agreement between the two methods of biomass estimations (Vidussi et al., 2004; Coupel et al., 2015; Mendes et al., 2012). For Phaeocystis, a positive relationship between the two methods of biomass estimation (CHEMTAX and microscopy) confirms that using chlorophyll $c 3$ was appropriate for detecting and quantifying Phaeocystis biomass in the Labrador Sea. Similar associations have been observed for Phaeocystis from 
boreal waters (e.g. P. pouchetii and P. globosa), which lacks or has low 19-hexanoyloxyfucoxanthin (Antajan et al., 2004; Muylaert et al., 2006; Stuart et al., 2000; Wassmann et al., 1990). Conversely, 19-hexanoyloxyfucoxanthin is a characteristic pigment marker of Phaeocystis from austral waters (P. antarctica) (Arrigo et al., 2010, 2014; Fragoso, 2009; Fragoso and Smith, 2012). Dinoflagellates gave a poor correlation between biomass estimates made using the two methods $\left(r^{2}=0.12\right.$, data not shown). A lack of or weak relationship between both biomass estimations for dinoflagellates has been previously reported in Arctic waters (Vidussi et al., 2004; Coupel et al., 2005). The argument for this inconsistency is that some heterotrophic dinoflagellates, which usually lack photosynthetic pigments, unless they ingest a prey that contains them, might have been included in the microscopic counts, and it is possible that the same occurred in Fragoso et al. (2016). Cryptophyte biomass estimates from both methods were not related (data not shown), likely as the biomass of this group was underestimated in microscopic counts. Inconsistences between CHEMTAX and microscopy methods of estimating biomasses have also been observed in nanoflagellates and this is assumed to be because of the low accuracy of visual microscopic counts (Coupel et al., 2015; Gieskes and Kraay, 1983).

\section{Conclusions}

In this study, we have provided a geographical description of phytoplankton community structure in spring and early summer surface waters of the Labrador Sea based on pigment data from over a decade of sampling (2005-2014). Phytoplankton communities and their photophysiological and biogeochemical signatures were assessed using CHEMTAX, so that a geographical baseline of the major phytoplankton groups has been provided for the central Labrador Sea and its adjacent continental shelves. In spite of interannual variability (due to differences in survey dates and natural variability), spring phytoplankton communities showed distinct spatial variations from east to west and there were clear temporal differences between May and June. The conclusions of our study are that: (1) phytoplankton communities varied among the distinct regions of the Labrador Sea; (2) temperature, salinity, and nutrient concentrations (nitrate, silicate, and phosphate) were statistically linked to the distribution of different phytoplankton communities; (3) in spite of some temporal variability, the distinct communities tended to reoccur in the same biogeographical regions, particularly at the shelves; (4) a strong temporal progression was observed in the central region of the Labrador Sea, where pre-bloom conditions in May were characterized by a diverse, mixed assemblage of flagellates, whilst blooms of diatoms and dinoflagellates occurred in June; (5) diatoms contributed the most to chlorophyll $a$ in bloom conditions (>3 $\mathrm{mg} \mathrm{Chl} a_{\mathrm{f}} \mathrm{m}^{-3}$ ), whilst other groups (chlorophytes, di- noflagellates, and Phaeocystis) co-dominated and were geographically segregated within distinct hydrographical zones; (6) distinct phytoplankton communities had different photophysiological characteristics (level of photoinhibition, photosynthetic efficiency, photosynthetic rate, saturation irradiance) and ratios of accessory pigments to total chlorophyll $a$, revealing distinct photo-adaptation strategies as a response to environmental conditions; and (7) $\mathrm{POC}_{\text {phyto }}$ and POC: PON ratios were directly influenced by phytoplankton community composition, although the latter was also influenced by freshwater input of allochthonous carbon in shelf waters (i.e. melting glacial and sea ice and local river outflows).

Data availability. Data included in the paper are available from various sources: via the BioChem repository (http://www. dfo-mpo.gc.ca/science/data-donnees/biochem/index-eng.html) and via the BODC data repository (www.bodc.ac.uk), and are compiled in Fragoso et al. (2017). Data are available at doi:10.1594/PANGAEA.871872 (Fragoso et al., 2017).

\section{The Supplement related to this article is available online at doi:10.5194/bg-14-1235-2017-supplement.}

Competing interests. The authors declare that they have no conflict of interest.

Acknowledgements. We would like to thank Sinhue Torres-Valdes, Mark Stinchcombe and Brian King (National Oceanography Centre) for collecting the samples and providing the nutrient and hydrographic data from JR302 cruise. Many thanks to Carol Anstey, Jeff Anning, and Tim Perry (Bedford Institute of Oceanography) for collecting and analysing nutrient concentrations, phytoplankton pigments, and photosynthetic measurements. The officers and crew of the CCGS Hudson and RSS James Clark Ross and the support of technicians and scientists from all cruises in analysing and providing the chlorophyll, particulate organic carbon, and nitrogen and hydrographic data are also acknowledged. We would like to thank Simon Wright (Australian Antarctic Division) for providing us with a copy of the CHEMTAX software v.1.95. We are grateful to Simon Wright and two other reviewers who offered useful suggestions to improve the manuscript. G. M. Fragoso was funded by a Brazilian PhD studentship, Science without Borders (CNPq, 201449/2012-9). This research was also partially funded by UK Ocean Acidification, a National Environment Research Council grant (NE/H017097/1) through an added value award to A. J. Poulton.

Edited by: K. Suzuki

Reviewed by: S. W. Wright and two anonymous referees 


\section{References}

Aiken, J., Pradhan, Y., Barlow, R., Lavender, S., Poulton, A., Holligan, P., and Hardman-Mountford, N.: Phytoplankton pigments and functional types in the Atlantic Ocean: A decadal assessment, 1995-2005, Deep-Sea Res. Pt. II, 56, 899-917, doi:10.1016/j.dsr2.2008.09.017, 2009.

Alderkamp, A.-C., Buma, A. G. J., and van Rijssel, M.: The carbohydrates of Phaeocystis and their degradation in the microbial food web, Biogeochemistry, 83, 99-118, doi:10.1007/s10533007-9078-2, 2007.

Alou-Font, E., Roy, S., Agustí, S., and Gosselin, M.: Cell viability, pigments and photosynthetic performance of Arctic phytoplankton in contrasting ice-covered and open-water conditions during the spring - summer transition, Mar. Ecol.-Prog. Ser., 543, 89106, doi:10.3354/meps11562, 2016.

Antajan, E., Chrétiennot-Dinet, M.-J., Leblanc, C., Daro, M.-H., and Lancelot, C.: 19'-hexanoyloxyfucoxanthin may not be the appropriate pigment to trace occurrence and fate of Phaeocystis: the case of $P$. globosa in Belgian coastal waters, J. Sea Res., 52, 165-177, doi:10.1016/j.seares.2004.02.003, 2004.

Arrigo, K. R.: Phytoplankton community structure and the drawdown of nutrients and $\mathrm{CO}_{2}$ in the Southern Ocean, Science, 283, 365-367, doi:10.1126/science.283.5400.365, 1999.

Arrigo, K. R., Mills, M. M., Kropuenske, L. R., Van Dijken, G. L., Alderkamp, A. C., and Robinson, D. H.: Photophysiology in two major southern ocean phytoplankton taxa: Photosynthesis and growth of Phaeocystis antarctica and Fragilariopsis cylindrus under different irradiance levels, Integr. Comp. Biol., 50, 950-966, doi:10.1093/icb/icq021, 2010.

Arrigo, K. R., Brown, Z. W. and Mills, M. M.: Sea ice algal biomass and physiology in the Amundsen Sea, Antarctica, Elem. Sci. Anthr., 2(1), 28 p., doi:10.12952/journal.elementa.000028, 2014.

Barton, A. D., Finkel, Z. V, Ward, B. A., Johns, D. G., and Follows, M. J.: On the roles of cell size and trophic strategy in North Atlantic diatom and dinoflagellate communities, Limnol. Oceanogr., 58, 254-266, doi:10.4319/lo.2013.58.1.0254, 2013.

Bertilsson, S., Berglund, O., Karl, D. M., and Chisholm, S. W.: Elemental composition of marine Prochlorococcus and Synechococcus: Implications for the ecological stoichiometry of the sea, Limnol. Oceanogr., 48, 1721-1731, doi:10.4319/lo.2003.48.5.1721, 2003.

Bouman, H., Platt, T., Sathyendranath, S., Li, W., Stuart, V., Fuentes-Yaco, C., Maass, H., Horne, E., Ulloa, O., Lutz, V., and Kyewalyanga, M.: Temperature as indicator of optical properties and community structure of marine phytoplankton: implications for remote sensing, Mar. Ecol.-Prog. Ser., 258, 19-30, doi:10.3354/meps258019, 2003.

Bouman, H., Platt, T., Sathyendranath, S., and Stuart, V.: Dependence of light-saturated photosynthesis on temperature and community structure, Deep-Sea Res. Pt. I, 52, 1284-1299, doi:10.1016/j.dsr.2005.01.008, 2005.

Boyton, W. R., Hall, C. A., Falkowiski, P. G., Keefe, C. W., and Kemp, W. M.: Phytoplankton productivity in aquatic ecosystems, in: Physiological Plant Ecology IV, Spring Berlin Heidelberg, 305-327, 1983.

Browning, T. J., Bouman, H. A., Moore, C. M., Schlosser, C., Tarran, G. A., Woodward, E. M. S., and Henderson, G. M.: Nutrient regimes control phytoplankton ecophysiology in the South
Atlantic, Biogeosciences, 11, 463-479, doi:10.5194/bg-11-4632014, 2014.

Chanut, J., Barnier, B., Large, W., Debreu, L., Penduff, T., Molines, J. M., and Mathiot, P.: Mesoscale eddies in the Labrador Sea and their contribution to convection and restratification, J. Phys. Oceanogr., 38, 1617-1643, doi:10.1175/2008JPO3485.1, 2008.

Clarke, K. R. and Warwick, R. M.: Change in marine communities: an approach to statistical analysis and interpretation, 2nd Edn., PRIMER-E, Plymouth, 2001.

Cota, G. F.: Bio-optical properties of the Labrador Sea, J. Geophys. Res., 108, 3228, doi:10.1029/2000JC000597, 2003.

Coupel, P., Jin, H. Y., Joo, M., Horner, R., Bouvet, H. A., Sicre, M.-A., Gascard, J.-C., Chen, J. F., Garçon, V., and RuizPino, D.: Phytoplankton distribution in unusually low sea ice cover over the Pacific Arctic, Biogeosciences, 9, 4835-4850, doi:10.5194/bg-9-4835-2012, 2012.

Coupel, P., Matsuoka, A., Ruiz-Pino, D., Gosselin, M., Marie, D., Tremblay, J.-É., and Babin, M.: Pigment signatures of phytoplankton communities in the Beaufort Sea, Biogeosciences, 12, 991-1006, doi:10.5194/bg-12-991-2015, 2015.

Crawford, D. W., Wyatt, S. N., Wrohan, I. A., Cefarelli, A. O., Giesbrecht, K. E., Kelly, B., and Varela, D. E.: Low particulate carbon to nitrogen ratios in marine surface waters of the Arctic, Global Biogeochem. Cy., 29, 2021-2033, doi:10.1002/2015GB005200, 2015.

Daly, K. L., Wallace, D. W. R., Smith, W. O., Skoog, A., Lara, R., Gosselin, M., Falck, E., and Yager, P. L.: Non-Redfield carbon and nitrogen cycling in the Arctic: Effects of ecosystem structure and dynamics, J. Geophys. Res.-Oceans, 104, 3185-3199, doi:10.1029/1998JC900071, 1999.

DiTullio, G. R., Garcia, N., Riseman, S. F., and Sedwick, P. N.: Effects of iron concentration on pigment composition in Phaeocystis antarctica grown at low irradiance, in: Phaeocystis, major link in the biogeochemical cycling of climate-relevant elements, Springer Netherlands, Dordrecht, 71-81, 2007.

Drinkwater, K. F., Belgrano, A., Borja, A., Conversi, A., Edwards, M., Greene, C. H., Ottersen, G., Pershing, A. J., and Walker, H.: the response of marine ecosystems to climate variability associated with the North Atlantic Oscillation, in: The North Atlantic Oscillation: Climatic Significance and Environmental Impact, 211-234, doi:10.1029/134GM10, 2003.

Finkel, Z. V., Quigg, A., Raven, J. A., Reinfelder, J. R., Schofield, O. E., and Falkowski, P. G.: Irradiance and the elemental stoichiometry of marine phytoplankton, Limnol. Oceanogr., 51, 2690 2701, doi:10.4319/lo.2006.51.6.2690, 2006.

Follows, M. J., Dutkiewicz, S., Grant, S., and Chisholm, S. W.: Emergent biogeography of microbial communities in a model ocean, Science, 315, 1843-1846, doi:10.1126/science.1138544, 2007.

Fragoso, G. M.: Hydrography and phytoplankton distribution in the Amundsen and Ross Seas, College of William and Mary, 2009.

Fragoso, G. M. and Smith, W. O.: Influence of hydrography on phytoplankton distribution in the Amundsen and Ross Seas, Antarctica, J. Mar. Syst., 89, 19-29, doi:10.1016/j.jmarsys.2011.07.008, 2012.

Fragoso, G. M., Poulton, A. J., Yashayaev, I. M., Head, E. J. H., Stinchcombe, M. C., and Purdie, D. A.: Biogeographical patterns and environmental controls of phytoplankton communities from contrasting hydrographical zones of the Labrador Sea, Prog. 
Oceanogr., 141, 212-226, doi:10.1016/j.pocean.2015.12.007, 2016.

Fragoso, G. M., Poulton, A. J., Yashayaev, I. M., Head, E. J. H., and Purdie, D. A.: Spring phytoplankton communities of the Labrador Sea (2005-2014): pigment signatures, photophysiology and elemental ratios, doi:10.1594/PANGAEA.871872, 2017.

Frajka-Williams, E. and Rhines, P. B.: Physical controls and interannual variability of the Labrador Sea spring phytoplankton bloom in distinct regions, Deep. Res. Pt. I, 57, 541-552, doi:10.1016/j.dsr.2010.01.003, 2010.

Frajka-Williams, E., Rhines, P. B., and Eriksen, C. C.: Physical controls and mesoscale variability in the Labrador Sea spring phytoplankton bloom observed by Seaglider, Deep. Res. Pt. I, 56, 2144-2161, doi:10.1016/j.dsr.2009.07.008, 2009.

Fujiwara, A., Hirawake, T., Suzuki, K., Imai, I., and Saitoh, S. I.: Timing of sea ice retreat can alter phytoplankton community structure in the western Arctic Ocean, Biogeosciences, 11, 17051716, doi:10.5194/bg-11-1705-2014, 2014.

Gieskes, W. W. C. and Kraay, G. W.: Dominance of Cryptophyceae during the phytoplankton spring bloom in the central North Sea detected by HPLC analysis of pigments, Mar. Biol., 75, 179-185, doi:10.1007/BF00406000, 1983.

Goffart, A., Catalano, G., and Hecq, J. H.: Factors controlling the distribution of diatoms and Phaeocystis in the Ross Sea, J. Mar. Syst., 27, 161-175, 2000.

Gradinger: Occurrence of an algal bloom under Arctic pack ice, Mar. Ecol.-Prog. Ser., 131, 301-305, 1996.

Gregg, W. W. and Casey, N. W.: Modeling coccolithophores in the global oceans, Deep-Sea Res. Pt. II, 54, 447-477, doi:10.1016/j.dsr2.2006.12.007, 2007.

Gregg, W. W., Ginoux, P., Schopf, P. S., and Casey, N. W.: Phytoplankton and iron: validation of a global three-dimensional ocean biogeochemical model, Deep-Sea Res. Pt. II, 50, 3143-3169, doi:10.1016/j.dsr2.2003.07.013, 2003.

Guidi, L., Stemmann, L., Jackson, G. A., Ibanez, F., Claustre, H., Legendre, L., Picheral, M., and Gorsky, G.: Effects of phytoplankton community on production, size, and export of large aggregates: A world-ocean analysis, Limnol. Oceanogr., 54, 19511963, doi:10.4319/lo.2009.54.6.1951, 2009.

Harrison, G. W., Yngve Børsheim, K., Li, W. K. W., Maillet, G. L., Pepin, P., Sakshaug, E., Skogen, M. D., and Yeats, P. A.: Phytoplankton production and growth regulation in the Subarctic North Atlantic: A comparative study of the Labrador Sea-Labrador/Newfoundland shelves and Barents/Norwegian/Greenland seas and shelves, Prog. Oceanogr., 114, 26-45, doi:10.1016/j.pocean.2013.05.003, 2013.

Harrison, W. G. and Platt, T.: Photosynthesis-irradiance relationships in polar and temperate phytoplankton populations, Polar Biol., 5, 153-164, 1986.

Hays, G., Richardson, A., and Robinson, C.: Climate change and marine plankton, Trends Ecol. Evol., 20, 337-344, doi:10.1016/j.tree.2005.03.004, 2005.

Head, E., Harris, L., and Campbell, R.: Investigations on the ecology of Calanus spp. in the Labrador Sea. I. Relationship between the phytoplankton bloom and reproduction and development of Calanus finmarchicus in spring, Mar. Ecol.-Prog. Ser., 193, 5373, doi:10.3354/meps193053, 2000.
Head, E. J. H. and Harris, L. R.: Chlorophyll destruction by Calanus spp. grazing on phytoplankton: Kinetics, effects of ingestion rate and feeding history, and a mechanistic interpretation, Mar. Ecol.-Prog. Ser., 135, 223-235, doi:10.3354/meps135223, 1996.

Head, E. J. H. and Pepin, P.: Spatial and inter-decadal variability in plankton abundance and composition in the Northwest Atlantic (1958-2006), J. Plankton Res., 32, 1633-1648, doi:10.1093/plankt/fbq090, 2010.

Head, E. J. H., Harris, L. R., and Yashayaev, I.: Distributions of Calanus spp. and other mesozooplankton in the Labrador Sea in relation to hydrography in spring and summer (1995-2000), Prog. Oceanogr., 59, 1-30, doi:10.1016/S0079-6611(03)001113, 2003.

Head, E. J. H., Melle, W., Pepin, P., Bagøien, E. and Broms, C.: On the ecology of Calanus finmarchicus in the Subarctic North Atlantic: A comparison of population dynamics and environmental conditions in areas of the Labrador Sea-Labrador/Newfoundland Shelf and Norwegian Sea Atlantic and Coastal Waters, Prog. Oceanogr., 114, 46-63, doi:10.1016/j.pocean.2013.05.004, 2013.

Henson, S., Lampitt, R., and Johns, D.: Variability in phytoplankton community structure in response to the North Atlantic Oscillation and implications for organic carbon flux, Limnol. Oceanogr., 57, 1591-1601, doi:10.4319/lo.2012.57.6.1591, 2012.

Higgins, H. W., Wright, S. W., and Schlüter, L.: Quantitative interpretation of chemotaxonomic pigment data, in: Phytoplankton Pigments: Characterization, Chemotaxonomy and Applications in Oceanography, edited by: Roy, S., Llewellyn, C., Egeland, E. S., and Johnsen, G., Cambridge University Press, Cambridge, 257-313, 2011.

Hill, V., Cota, G. and Stockwell, D.: Spring and summer phytoplankton communities in the Chukchi and Eastern Beaufort Seas, Deep. Res. Pt. II, 52, 3369-3385, doi:10.1016/j.dsr2.2005.10.010, 2005.

Ho, T., Quigg, A., Zoe, V., Milligan, A. J., Wyman, K., Falkowski, P. G., and Morel, F. M. M.: The elemental composition of some marine phytoplankton, J. Phycol., 1159, 1145-1159, 2003.

Holm-Hansen, O., Lorenzen, C. J., Holmes, R. W., and Strickland, J. D. H.: Fluorometric determination of chlorophyll, ICES J. Mar Sci., 30, 3-15, doi:10.1093/icesjms/30.1.3, 1965.

Hood, E., Battin, T. J., Fellman, J., Neel, S. O., and Spencer, R. G. M.: Storage and release of organic carbon from glaciers and ice sheets, Nat. Geosci., 8, 91-96, doi:10.1038/ngeo2331, 2015.

Huot, Y., Babin, M., and Bruyant, F.: Photosynthetic parameters in the Beaufort Sea in relation to the phytoplankton community structure, Biogeosciences, 10, 3445-3454, doi:10.5194/bg10-3445-2013, 2013.

International Hydrographic Organization: Limits of Oceans and Seas, Special Publication 23, 3rd Edn., Monaco, International Hydrographic Organization, 1953.

Irigoien, X., Meyer, B., Harris, R., and Harbour, D.: Using HPLC pigment analysis to investigate phytoplankton taxonomy: The importance of knowing your species, Helgoland Mar. Res., 58, 77-82, doi:10.1007/s10152-004-0171-9, 2004.

Jeffrey, S. W., Mantoura, R. F. C., and Wright, S. W.: Phytoplankton Pigments in Oceanography, SCOR and UNESCO, Paris, 1997.

Kropuenske, L. R., Mills, M. M., van Dijken, G. L., Bailey, S., Robinson, D. H., Welschmeyer, N. A., and Arrigo, K. 
R.: Photophysiology in two major Southern Ocean phytoplankton taxa: Photoprotection in Phaeocystis antarctica and Fragilariopsis cylindrus, Limnol. Oceanogr., 54, 1176-1196, doi:10.4319/lo.2009.54.4.1176, 2009.

Lacour, L., Claustre, H., Prieur, L., and Ortenzio, F. D.: Phytoplankton biomass cycles in the North Atlantic subpolar gyre: A similar mechanism for two different blooms in the Labrador Sea, Geophys. Res. Lett., 42, 5403-5410, doi:10.1002/2015GL064540, 2015.

Latasa, M.: Improving estimations of phytoplankton class abundances using CHEMTAX, Mar. Ecol.-Prog. Ser., 329, 13-21, doi:10.3354/meps329013, 2007.

Lee, S. and Fuhrman, J. E. D. A.: Relationships between biovolume and biomass of naturally derived marine bacterioplankton, DeepSea Res. Pt. B., 34, 1069, doi:10.1016/0198-0254(87)96080-8, 1987.

Le Moigne, F. A. C., Poulton, A. J., Henson, S. A., Daniels, C. J., Fragoso, G. M., Mitchell, E., Richier, S., Russell, B. C., Smith, H. E. K., Tarling, G. A., Young, J. R., and Zubkov, M.: Carbon export efficiency and phytoplankton community composition in the Atlantic sector of the Arctic Ocean, J. Geophys. Res.-Oceans, 120, 3896-3912, doi:10.1002/2015JC010700.Received, 2015.

Leterme, S. C., Edwards, M., Seuront, L., Attrill, M. J., Reid, P. C., and John, A. W. G.: Decadal basin-scale changes in diatoms, dinoflagellates, and phytoplankton color across the North Atlantic, Limnol. Oceanogr., 50, 1244-1253, 2005.

Li, W. K. W. and Harrison, W. G.: Chlorophyll, bacteria and picophytoplankton in ecological provinces of the North Atlantic, Deep. Res. Pt. II, 48, 2271-2293, doi:10.1016/S09670645(00)00180-6, 2001.

Li, W. K. W., Harrison, W. G., and Head, E. J. H.: Coherent assembly of phytoplankton communities in diverse temperate ocean ecosystems, Proc. Biol. Sci., 273, 1953-1960, doi:10.1098/rspb.2006.3529, 2006.

Litchman, E. and Klausmeier, C. A.: Trait-based community ecology of phytoplankton, Annu. Rev. Ecol. Evol. S., 39, 615-639, doi:10.1146/annurev.ecolsys.39.110707.173549, 2008.

Lovejoy, C., Legendre, L., Martineau, M.-J., Bâcle, J., and von Quillfeldt, C. H.: Distribution of phytoplankton and other protists in the North Water, Deep-Sea Res. Pt. II, 49, 5027-5047, doi:10.1016/S0967-0645(02)00176-5, 2002.

Lovejoy, C., Vincent, W. F., Bonilla, S., Roy, S., Martineau, M.-J., Terrado, R., Potvin, M., Massana, R., and Pedrós-Alió, C.: Distribution, phylogeny, and growth of cold-adapted picoprasinophytes in Arctic Seas, J. Phycol., 43, 78-89, doi:10.1111/j.15298817.2006.00310.x, 2007.

Lutz, V. A., Sathyendranath, S., Head, E. J. H., and Li, W. K. W.: Variability in pigment composition and optical characteristics of phytoplankton in the Labrador Sea and the Central North Atlantic, Mar. Ecol.-Prog. Ser., 260, 1-18, doi:10.3354/meps260001, 2003.

MacIntyre, H. L., Lawrenz, E., and Richardson, T. L.: Taxonomic discrimination of phytoplankton by spectral fluorescence, in: Chlorophyll a fluorescence in aquatic sciences: methods and applications, 129-169, Springer Netherlands, 2010.

Mackey, M. D., Mackey, D. J., Higgins, H. W., and Wright, S. W.: CHEMTAX - a program for estimating class abundances from chemical markers: application to HPLC measurements of phytoplankton, Mar. Ecol.-Prog. Ser., 144, 265-283, 1996.
Martiny, A. C., Vrugt, J. A., Primeau, F. W., and Lomas, M. W.: Regional variation in the particulate organic carbon to nitrogen ratio in the surface ocean, Global Biogeochem. Cy., 27, 723-731, doi:10.1002/gbc.20061, 2013a.

Martiny, A. C., Pham, C. T. A., Primeau, F. W., Vrugt, J. A., Moore, J. K., Levin, S. A., and Lomas, M. W.: Strong latitudinal patterns in the elemental ratios of marine plankton and organic matter, Nat. Geosci., 6, 279-283, doi:10.1038/ngeo1757, 2013b.

Mei, Z.-P., Legendre, L., Tremblay, J.-E., Miller, L. A., Gratton, Y., Lovejoy, C., Yager, P. L., and Gosselin, M.: Carbon to nitrogen $(\mathrm{C}: \mathrm{N})$ stoichiometry of the spring - summer phytoplankton bloom in the North Water Polynya (NOW), Deep-Sea Res. Pt. I, 52, 2301-2314, doi:10.1016/j.dsr.2005.07.001, 2005.

Moisan, T. A., Olaizola, M., and Mitchell, B. G.: Xanthophyll cycling in Phaeocystis antarctica: Changes in cellular fluorescence, Mar. Ecol.-Prog. Ser., 169, 113-121, doi:10.3354/meps169113, 1998.

Muylaert, K., Gonzales, R., Franck, M., Lionard, M., Van der Zee, C., Cattrijsse, A., Sabbe, K., Chou, L., and Vyverman, W.: Spatial variation in phytoplankton dynamics in the Belgian coastal zone of the North Sea studied by microscopy, HPLC-CHEMTAX and underway fluorescence recordings, J. Sea Res., 55, 253-265, doi:10.1016/j.seares.2005.12.002, 2006.

Ondrusek, M. E., Bidigare, R. R., Sweet, S. T., Defreitas, D. A., and Brooks, J. M.: Distribution of phytoplankton pigments in the North Pacific Ocean in relation to physical and optical variability, Deep. Res., 38, 243-266, 1991.

Palmer, M. A., Arrigo, K. R., Mundy, C. J., Ehn, J. K., Gosselin, M., Barber, D. G., Martin, J., Alou-Font, E., Roy, S., and Tremblay, J.-É.: Spatial and temporal variation of photosynthetic parameters in natural phytoplankton assemblages in the Beaufort Sea, Canadian Arctic, Polar Biol., 34, 1915-1928, doi:10.1007/s00300-011-1050-x, 2011.

Palmisano, A. C., Soohoo, J. B., Soohoo, S. L., Kottmeier, S. T., Craft, L. L., and Sullivan, C. W.: Photoadaptation in Phaeocystis pouchetii advected beneath annual sea ice in Mcmurdo Sound, Antarctica, J. Plankton Res., 8, 891-906, 1986.

Palter, J. B., Caron, C.-A., Law, K. L., Willis, J. K., Trossman, D. S., Yashayaev, I. M., and Gilbert, D.: Variability of the directly observed, middepth subpolar North Atlantic circulation, Geophys. Res. Lett., 43, 2700-2708, doi:10.1002/2015GL067235, 2016.

Peloquin, J., Swan, C., Gruber, N., Vogt, M., Claustre, H., Ras, J., Uitz, J., Barlow, R., Behrenfeld, M., Bidigare, R., Dierssen, H., Ditullio, G., Fernandez, E., Gallienne, C., Gibb, S., Goericke, R., Harding, L., Head, E., Holligan, P., Hooker, S., Karl, D., Landry, M., Letelier, R., Llewellyn, C. A., Lomas, M., Lucas, M., Mannino, A., Marty, J.-C., Mitchell, B. G., Muller-Karger, F., Nelson, N., O’Brien, C., Prezelin, B., Repeta, D., Jr. Smith, W. O., Smythe-Wright, D., Stumpf, R., Subramaniam, A., Suzuki, K., Trees, C., Vernet, M., Wasmund, N., and Wright, S.: The MAREDAT global database of high performance liquid chromatography marine pigment measurements, Earth Syst. Sci. Data, 5, 109123, doi:10.5194/essd-5-109-2013, 2013.

Pepin, P. and Head, E. J. H.: Seasonal and depth-dependent variations in the size and lipid contents of stage 5 copepodites of Calanus finmarchicus in the waters of the Newfoundland Shelf and the Labrador Sea, Deep-Sea Res. Pt. I, 56, 989-1002, doi:10.1016/j.dsr.2009.01.005, 2009. 
Piquet, A. M.-T., van de Poll, W. H., Visser, R. J. W., Wiencke, C., Bolhuis, H., and Buma, A. G. J.: Springtime phytoplankton dynamics in Arctic Krossfjorden and Kongsfjorden (Spitsbergen) as a function of glacier proximity, Biogeosciences, 11, 22632279, doi:10.5194/bg-11-2263-2014, 2014.

Platt, T. and Gallegos, C. L.: Modelling Primary Production, in: Primary productivity in the sea, vol. 19, edited by: Falkowski, P. G., 339-362, Springer, US, 1980.

Platt, T., Bouman, H., Devred, E., Fuentes-Yaco, C., and Sathyendranath, S.: Physical forcing and phytoplankton distributions, Sci. Mar., 69, 55-73, doi:10.3989/scimar.2005.69s155, 2005.

Poulton, A. J., Holligan, P. M., Hickman, A., Kim, Y. N., Adey, T. R., Stinchcombe, M. C., Holeton, C., Root, S., and Woodward, E. M. S.: Phytoplankton carbon fixation, chlorophyll-biomass and diagnostic pigments in the Atlantic Ocean, Deep. Res. Pt. II, 53, 1593-1610, doi:10.1016/j.dsr2.2006.05.007, 2006.

Quigg, A., Irwin, A. J., and Finkel, Z. V.: Evolutionary inheritance of elemental stoichiometry in phytoplankton, P. R. Soc. B, 278, 526-534, doi:10.1098/rspb.2010.1356, 2003.

Redfield, A. C.: The biological control of chemical factors in the environment, Am. Sci., 46, 205-221, 1958.

Rhee, G.-Y.: Effects of $\mathrm{N}: \mathrm{P}$ atomic ratios and nitrate limitation on algal growth, cell composition, and nitrate uptake, Limnol. Oceanogr., 23, 10-25, doi:10.4319/lo.1978.23.1.0010, 1978.

Sarthou, G., Timmermans, K. R., Blain, S., and Tréguer, P.: Growth physiology and fate of diatoms in the ocean: A review, J. sea, 53, 25-42, doi:10.1016/j.seares.2004.01.007, 2005.

Sathyendranath, S., Longhurst, A., Caverhill, C. M., and Platt, T.: Regionally and seasonally differentiated primary production in the North Atlantic, Deep. Res., 42, 1773-1802, 1995.

Sathyendranath, S., Watts, L., Devred, E., Platt, T., Caverhill, C., and Maass, H.: Discrimination of diatoms from other phytoplankton using ocean-colour data, Mar. Ecol.-Prog. Ser., 272, 59-68, doi:10.3354/meps272059, 2004.

Sathyendranath, S., Stuart, V., Nair, A., Oka, K., Nakane, T., Bouman, H., Forget, M. H., Maass, H., and Platt, T.: Carbonto-chlorophyll ratio and growth rate of phytoplankton in the sea, Mar. Ecol.-Prog. Ser., 383, 73-84, doi:10.3354/meps07998, 2009.

Smith, W. O. and Asper, V. L.: The influence of phytoplankton assemblage composition on biogeochemical characteristics and cycles in the southern Ross Sea, Antarctica, Deep. Res. Pt. I., 48, 137-161, doi:10.1016/S0967-0637(00)00045-5, 2001.

Stramska, M., Stramski, D., Kaczmarek, S. J., Allison, D. B., and Schwarz, J.: Seasonal and regional differentiation of bio-optical properties within the north polar Atlantic, J. Geophys. Res., 111, 1-16, doi:10.1029/2005JC003293, 2006.

Stuart, V. and Head, E. J. H.: The BIO method, in: The second SeaWiFS HPLC analysis round-robin experiment (SeaHARRE2), edited by: Hooker, S. B., van Heukelem, L., Thomas, C. S., Claustre, H., Ras, J., Barlow, R., Sessions, H., Schluter, L., Perl, J., Trees, C., Stuart, V., Head, E., Clementson, L., Fishwick, J., Llewellyn, C. A., and Aiken, J., 78-80, 2005.

Stuart, V., Sathyendranath, S., Head, E. J. H., Platt, T., Irwin, B., and Maass, H.: Bio-optical characteristics of diatom and prymnesiophyte populations in the Labrador Sea, Mar. Ecol.-Prog. Ser., 201, 91-106, doi:10.3354/meps201091, 2000.

Swan, C. M., Vogt, M., Gruber, N., and Laufkoetter, C.: A global seasonal surface ocean climatology of phytoplankton types based on CHEMTAX analysis of HPLC pigments, Deep. Res. Pt. I, 109, 137-156, doi:10.1016/j.dsr.2015.12.002, 2015.

Tamelander, T., Aubert, A. B., and Riser, C. W.: Export stoichiometry and contribution of copepod faecal pellets to vertical flux of particulate organic carbon, nitrogen and phosphorus, Mar. Ecol.Prog. Ser., 459, 17-28, doi:10.3354/meps09733, 2012.

Thompson, P. A., Bonham, P., Waite, A. M., Clementson, L. A., Cherukuru, N., Hassler, C., and Doblin, M. A.: Contrasting oceanographic conditions and phytoplankton communities on the east and west coasts of Australia, Deep-Sea Res. Pt. II, 58, 645663, doi:10.1016/j.dsr2.2010.10.003, 2011.

Tortell, P. D., DiTullio, G. R., Sigman, D. M., and Morel, F. M. M.: $\mathrm{CO}_{2}$ effects on taxonomic composition and nutrient utilization in an Equatorial Pacific phytoplankton assemblage, Mar. Ecol.Prog. Ser., 236, 37-43, doi:10.3354/meps236037, 2002.

Trees, C. C., Clark, D. K., Bidigare, R. R., Ondrusek, M. E., and Mueller, J. L.: Accessory pigments versus chlorophyll a concentrations within the euphotic zone: A ubiquitous relationship, Limnol. Oceanogr., 45, 1130-1143, 2000.

van Leeuwe, M. A. and Stefels, J.: Effects of iron and light stress on the biogeochemical composition of Antarctic Phaeocystis sp. (Prymnesiophyceae). II. Pigment composition, J. Phycol., 34, 496-503, 1998.

van Leeuwe, M. A. and Stefels, J.: Photosynthetic responses in Phaeocystis antarctica towards varying light and iron conditions, in: Phaeocystis, major link in the biogeochemical cycling of climate-relevant elements, Springer Netherlands, Dordrecht, 61-70, 2007.

Vidussi, F., Roy, S., Lovejoy, C., Gammelgaard, M., Thomsen, H. A., Booth, B., Tremblay, J.-E., and Mostajir, B.: Spatial and temporal variability of the phytoplankton community structure in the North Water Polynya, investigated using pigment biomarkers, Can. J. Fish. Aquat. Sci., 61, 2038-2052, doi:10.1139/f04-152, 2004.

Vrede, K., Heldal, M., Norland, S., and Bratbak, G.: Elemental composition $(\mathrm{C}, \mathrm{N}, \mathrm{P})$ and cell volume of exponentially growing and nutrient-limited bacterioplankton, Appl. Environ. Microbiol., 68, 2965-2971, doi:10.1128/AEM.68.6.2965-2971.2002, 2002.

Wang, Z., Brickman, D., Greenan, B. J. W., and Yashayaev, I.: An abrupt shift in the Labrador Current System in relation to winter NAO events, J. Geophys. Res.-Ocean., 121, 5338-5349, doi:10.1002/2016JC011721, 2016.

Wassmann, P., Vernet, M., Mitchell, B., and Rey, F.: Mass sedimentation of Phaeocystis pouchetii in the Barents Sea, Mar. Ecol.Prog. Ser., 66, 183-195, doi:10.3354/meps066183, 1990.

Weber, T. S. and Deutsch, C.: Ocean nutrient ratios governed by plankton biogeography, Nature, 467, 550-554, doi:10.1038/nature09403, 2010.

Weller, R. A. and Plueddemann, A. J.: Observations of the vertical structure of the oceanic boundary layer, J. Geophys. Res., 101, 8789, doi:10.1029/96JC00206, 1996.

Wolfe, G. V., Levasseur, M., Cantin, G., and Michaud, S.: DMSP and DMS dynamics and microzooplankton grazing in the Labrador Sea: application of the dilution technique, Deep-Sea Res. Pt. I, 47, 2243-2264, 2000.

Wright, S. W. and Van den Enden, R. L.: Phytoplankton community structure and stocks in the East Antarctic marginal ice zone (BROKE survey, January-March 1996) determined by CHEM- 
TAX analysis of HPLC pigment signatures, Deep. Res. Pt. II., 47, 2363-2400, doi:10.1016/S0967-0645(00)00029-1, 2000.

Wright, S. W., Thomas, D. P., Marchant, H. J., Higgins, H. W., Mackey, M. D., and Mackey, D. J.: Analysis of phytoplankton of the Australian sector of the Southern Ocean: Comparisons of microscopy and size frequency data with interpretations of pigment HPLC data using the "CHEMTAX" matrix factorisation program, Mar. Ecol.-Prog. Ser., 144, 285-298, doi:10.3354/meps144285, 1996.

Wright, S. W., Ishikawa, A., Marchant, H. J., Davidson, A. T., van den Enden, R. L., and Nash, G. V.: Composition and significance of picophytoplankton in Antarctic waters, Polar Biol., 32, 797808, doi:10.1007/s00300-009-0582-9, 2009.

Wu, Y., Peterson, I. K., Tang, C. C. L., Platt, T., Sathyendranath, S., and Fuentes-Yaco, C.: The impact of sea ice on the initiation of the spring bloom on the Newfoundland and Labrador Shelves, J. Plankton Res., 29, 509-514, doi:10.1093/plankt/fbm035, 2007.

Wu, Y., Platt, T., Tang, C., and Sathyendranath, S.: Regional differences in the timing of the spring bloom in the Labrador Sea, Mar. Ecol.-Prog. Ser., 355, 9-20, doi:10.3354/meps07233, 2008.

Yashayaev, I.: Hydrographic changes in the Labrador Sea, 1960-2005, Prog. Oceanogr., 73, 242-276, doi:10.1016/j.pocean.2007.04.015, 2007.
Yashayaev, I. and Loder, J. W.: Enhanced production of Labrador Sea Water in 2008, Geophys. Res. Lett., 36, doi:10.1029/2008GL036162, 2009.

Yashayaev, I. and Seidov, D.: The role of the Atlantic Water in multidecadal ocean variability in the Nordic and Barents Seas, Prog. Oceanogr., 132, 68-127, doi:10.1016/j.pocean.2014.11.009, 2015.

Yebra, L., Harris, R. P., Head, E. J. H., Yashayaev, I., Harris, L. R., and Hirst, A. G.: Mesoscale physical variability affects zooplankton production in the Labrador Sea, Deep-Sea Res. Pt. I, 56, 703-715, doi:10.1016/j.dsr.2008.11.008, 2009.

Zhai, L., Platt, T., Tang, C., Sathyendranath, S., and Walne, A.: The response of phytoplankton to climate variability associated with the North Atlantic Oscillation, Deep-Sea Res. Pt. II, 93, 159168, doi:10.1016/j.dsr2.2013.04.009, 2013.

Zhang, F., He, J., Lin, L., and Jin, H.: Dominance of picophytoplankton in the newly open surface water of the central Arctic Ocean, Polar Biol., 1081-1089, doi:10.1007/s00300-015-16627, 2015 